\title{
Evaluation of the pozzolanic activity of uncontrolled-combusted sewage sludge ash
}

\author{
Danilo Bordan Istuque ${ }^{1}$, Lucia Reig ${ }^{2}$, Lourdes Soriano ${ }^{3}$, Maria Victoria Borrachero ${ }^{4}$, José Luiz Pinheiro \\ Melges $^{5}$, Jorge Luis Akasaki ${ }^{6}$, Jorge Juan Payá Bernabeu ${ }^{7}$, Mauro Mitsuuchi Tashima ${ }^{8}$ \\ ${ }^{1}$ UNESP - Universidade Estadual Paulista "Júlio de Mesquita Filho", Faculdade de Engenharia de Ilha Solteira. MAC - Grupo de \\ Pesquisa em Materiais Alternativos de Construção. Ilha Solteira-SP, Brazil. \\ ${ }^{2}$ EMC, Universitat Jaume I, Av. de Vicent Sos Baynat s/n, 12071 Castello’ de la Plana, Spain. \\ ${ }^{3}$ ICITECH - Instituto de Ciencia y Tecnología del Hormigón. Universitat Politècnica de València (UPV). Valencia, Spain. \\ ${ }^{4}$ ICITECH - Instituto de Ciencia y Tecnología del Hormigón. Universitat Politècnica de València (UPV). Valencia, Spain. \\ ${ }^{5}$ UNESP - Universidade Estadual Paulista "Júlio de Mesquita Filho", Faculdade de Engenharia de Ilha Solteira. MAC - Grupo de \\ Pesquisa em Materiais Alternativos de Construção. Ilha Solteira-SP, Brazil. \\ ${ }^{6}$ UNESP - Universidade Estadual Paulista "Júlio de Mesquita Filho", Faculdade de Engenharia de Ilha Solteira. MAC - Grupo de \\ Pesquisa em Materiais Alternativos de Construção. Ilha Solteira-SP, Brazil. \\ ${ }^{7}$ ICITECH - Instituto de Ciencia y Tecnología del Hormigón. Universitat Politècnica de València (UPV). Valencia, Spain. \\ ${ }^{8}$ UNESP - Universidade Estadual Paulista "Júlio de Mesquita Filho", Faculdade de Engenharia de Ilha Solteira. MAC - Grupo de \\ Pesquisa em Materiais Alternativos de Construção. Ilha Solteira-SP, Brazil. *Corresponding author. Email: \\ mauro.tashima@unesp.br
}

\begin{abstract}
This paper evaluates the pozzolanic activity of sewage sludge ash (USSA) obtained following an uncontrolled-combustion process, a simple and economic procedure. Compressive strength of Portland cement/USSA mortars with different percentage of USSA (5-25 wt.\%) were evaluated, as well as calcium hydroxide/USSA (CH/USSA) and Portland cement/USSA (PC/USSA) pastes were chemically and physically characterised. The compressive strength of the mortars was increased as Portland cement replacement level by USSA was increased, reaching values $27 \%, 16 \%$ and $7 \%$ higher than the one corresponding to the reference mortar (0\% USSA) at 7, 28 and 90 curing days, respectively, with $25 \%$ USSA. The TG/DTG tests run in the CH/USSA pastes revealed the pozzolanic behaviour of USSA. The TG/DTG, FTIR, XRD, and SEM analyses performed in the PC/USSA pastes showed the formation of hydrated products such as C-S-H, C-A-S-H, and C-A-H from the pozzolanic reaction of USSA, which contributed to the compressive strength improvement.
\end{abstract}

Keywords: Sewage sludge ash (USSA); Pozzolan; Fixed portlandite; Waste valorisation; Uncontrolled combustion. 
Increasing amounts of sewage sludge, a waste generated in wastewater treatment plants, are yearly generated, which is mainly attributed to the urbanisation and improved sanitation systems of the cities. According to Krüger and Adam (Krüger and Adam 2015), 30 million tons/year of sewage sludge are generated by Europe, North America, and Japan (the sum of all of them). Kelessidis and Stasinakis (Kelessidis and Stasinakis 2012) also pointed out that it is expected that by 2020 the production of dry sewage sludge in the European Union will exceed 13 million tons. The large volume of sewage sludge generated prompted the development of technological plants to incinerate this waste while generating energy (Abuşoğlu et al. 2017; Donatello and Cheeseman 2013). Although this significantly reduces the volume of waste, the ash resulting from the process must also be adequately managed (Kliopova and

In this sense, previous studies successfully recovered phosphorous from SSA (Krüger and Adam 2015), Portland cement, pastes, mortars, bricks, tiles, ceramics or glass (Baeza-Brotons et al. 2014; Chen and Poon 2017; Dyer et al. 2011; Lin et al. 2007; Monzó et al. 2003; Perez Carrion et al. 2013; Smol et al. 2015; Tarrago et al. 2017; Tashima et al. 2017; Yusuf et al. 2012; Zhou et al. 2019). Reusing SSA in these of the sewage sludge incineration (Naamane et al. 2016; Oliva et al. 2019).

All the studies performed until now had in common that the temperature and time used to incinerate the sewage sludge were controlled (Chen et al. 2013; Cyr et al. 2007; Garcés et al. 2008; He et al. 2017; Li et al. 2019, 2017; Monzó et al. 2003; Naamane et al. 2016; Yusuf et al. 2012). However, controlled 
gang et al. 2016). As explained by Kelessidis and Stasinakis (Kelessidis and Stasinakis 2012), when the sewage sludge cannot be incinerated, the most common alternative is disposing of it in landfills. Therefore, using simple and economic methods of incineration would allow reusing this waste anywhere, regardless of the existence of incineration plants. The research reported here aimed to develop a simple route to incinerate sewage sludge, and to evaluate the reactivity of the resulting ash, which was called uncontrolledcombusted sewage sludge ash (USSA). The USSA was characterised (XRF, XRD, PSD, FTIR, and SEM analyses), and its pozzolanic behaviour was assessed using calcium hydroxide/USSA pastes (CH/USSA; TG/DTG analyses), Portland cement/USSA pastes (PC/USSA; TG/DTG, XRD, FTIR and SEM analyses), and PC/USSA mortars (compressive strength development).

\section{Materials and Methods}

\section{Materials}

Dewatered sewage sludge with relative humidity of 77\%, approximately, was collected in the São José do Rio Preto wastewater treatment plant (São Paulo, Brazil). Brazil. High purity calcium hydroxide (>95\% of $\mathrm{Ca}(\mathrm{OH})_{2}-$ "CH”) was used to prepare CH/USSA pastes. The Brazilian Portland Cement CP V ARI (PC) used to prepare pastes and mortars presented a clinker content greater than $95 \%$ and did not contain pozzolanic additions. Siliceous sand from Castilho city (São Paulo - Brazil), with a particle diameter lower than $2.36 \mathrm{~mm}$, a fineness modulus of 2.12 , and a specific gravity of $2.64 \mathrm{~g} / \mathrm{cm}^{3}$ was used to prepare the PC/USSA mortars.

\section{Methods}

\section{Incineration of sewage sludge}

The process followed to produce USSA is shown in Fig. 1. Firstly, around $3 \mathrm{~cm}$ layers of dewatered sewage sludge were dried by exposing them to solar radiation for four days. Secondly, the dried-granular sewage sludge was incinerated in an uncontrolled-combustion cylindrical chamber (200-litre volume). About $20 \mathrm{~kg}$ of dried-granular sewage sludge were put in the chamber, and free air circulation was initiated. To allow the combustion to initiate, gas was supplied in the bottom of this chamber during the first minute. The 
complete combustion of the dried-granular sewage sludge occurred by the propagation of the heat from the bottom to the top. This process was repeated several times until the amount of ash required to perform the study was produced. The temperature of the uncontrolled-combustion of the sewage sludge was monitored with a thermocouple installed inside the oven. As shown in Fig. 2, after 3 hours of combustion, a maximum average temperature of approximately $774^{\circ} \mathrm{C}$ was reached. The incineration of sewage sludge with a temperature above $500^{\circ} \mathrm{C}$ is important to loss of volatile components and decomposition of the organic matter, that in high content affects the mechanical properties of cementing materials (Chang et al. 2020). Furthermore, according to Naamane et al. (Naamane et al. 2016), as nearer to $800^{\circ} \mathrm{C}$ occurs the calcination of the sewage sludge, higher is the pozzolanic activity of generated ash. Finally, the granular sewage sludge ash was milled in a ball mill (USSA/ball weight ratio of 0.10 ) during 50 minutes to increase its pozzolanic reactivity (Donatello et al. 2010; Pan et al. 2003a). This incineration process provided approximately 43 wt.\% USSA regarding the sewage sludge mass incinerated.

1

Fig. 1. Process followed to obtain the uncontrolled-combusted sewage sludge ash.

Fig. 2. Temperature profile during the uncontrolled-combustion of the dried-granular sewage sludge.

\section{USSA characterisation}

The USSA was characterised by X-ray diffraction (XRD), Fourier transform infrared spectroscopy (FTIR), Scanning electron microscopy (SEM), X-ray fluorescence (XRF), laser diffraction granulometry, insoluble residue according to UNE-EN 196-2:2014, BET surface area according to ISO 9277:2010, density measured with pycnometer, and $\mathrm{pH}$ of $1 \mathrm{~g}$ USSA to $10 \mathrm{ml}$ deionized water, measured with pHmeter after $24 \mathrm{~h}$. The XRD tests were run to $2 \theta$ range of $5-60^{\circ}$, using $\mathrm{Cu}-\mathrm{K} \alpha$ radiation and a Ni filter at a voltage of $30 \mathrm{kV}$, a current intensity of $40 \mathrm{~mA}$, an angle step of $0.02^{\circ}$, and a step time of $1.20 \mathrm{~s} / \mathrm{step}$. FTIR analyses were performed in the wavenumber range of 400 to $4000 \mathrm{~cm}^{-1}$. SEM images using secondary electrons signal were obtained from the gold-covered surface of fractured pastes. 
117 Table 1 summarises the mix proportion and curing condition of the PC/USSA mortars developed. 118 Percentages between 0-25 wt.\% of PC were replaced by USSA, and the specimen which contained only PC 119 (0 wt.\% USSA) was prepared as a reference mortar. To all specimens, a constant water to cementitious

Table 1. Mix proportion of the PC/USSA mortars.

\section{Preparation and characterisation of the lime/USSA pastes (CH/USSA) and Portland cement/USSA pastes (PC/USSA)}

CH/USSA pastes were prepared using a CH:USSA mass ratio of 3:7 $(\mathrm{w} / \mathrm{cm}=0.8)$ and 1:1 $(\mathrm{w} / \mathrm{cm}=1)$, where $\mathrm{CH}$ and USSA was taken into account as cementitious materials $(\mathrm{cm})$. All these pastes were cured at $20{ }^{\circ} \mathrm{C}$ and $40{ }^{\circ} \mathrm{C}$ under high relative humidity conditions ( $\left.\mathrm{RH}>95 \%\right)$. TG/DTG analyses were carried out at $1,3,7$, and 28 curing days in the specimens cured at $40{ }^{\circ} \mathrm{C}$, and at 3,7 , and 28 curing days in those cured at $20^{\circ} \mathrm{C}$. The early TG/DTG test ( 1 day) for the pastes cured at $40{ }^{\circ} \mathrm{C}$ was performed to evaluate the acceleration of the pozzolanic reaction generated by temperature (Gastaldini et al. 2015).

PC/USSA pastes were prepared according to the mix proportions and curing conditions previously described in Table 1. TG/DTG and FTIR analyses were carried out in all the specimens, after 7, 28, and 90 curing days, to assess the microstructural development. The XRD tests were performed in the control paste 
and those containing $25 \mathrm{wt} . \%$ USSA, after being cured for 7, 28, and 90 days. SEM analyses were carried out only for the 0-USSA and 25-USSA pastes cured for 90 days.

The XRD, FTIR, and SEM analysis procedures were the same as those described in the USSA characterisation. An thermo-balance was used to analyse the pastes by thermogravimetry (TGA). The parameters employed for the TGA tests were as follows: temperature range, $35-600^{\circ} \mathrm{C}$; heating rate, 10 ${ }^{\circ} \mathrm{C} \cdot \mathrm{min}^{-1}$; and an atmosphere of $\mathrm{N}_{2}\left(75 \mathrm{~mL} \cdot \mathrm{min}^{-1}\right.$ flow $)$. The samples were tested in sealed aluminium crucibles $(100 \mu \mathrm{L})$ with a pinhole in the lid. Before those analyses, the pastes were grounded in an agate mortar, being the hydration process stopped with acetone as described by Moraes et al. (Moraes et al. 2016).

\section{Results and Discussion}

\section{USSA characterisation}

The physical characteristic and $\mathrm{pH}$ of USSA are summarized in Table 2. The USSA particle diameter size was significantly reduced after the milling process as can be seen in Fig. 3. The mean particle diameter of unmilled USSA was $199.41 \mu \mathrm{m}$, being composed of $50 \%(\mathrm{~d}(0.5))$ of particles with a diameter under 95.19 $\mu \mathrm{m}$ (Table 2), likely due to an agglomerated particles aspect generated by the combustion of the driedgranular sewage sludge (Fig. 1). A large mean particle diameter for unmilled SSA was also reported by some authors (Donatello et al. 2010). The mean particle diameter of milled USSA was $20.28 \mu \mathrm{m}$, with $\mathrm{d}(0.1), \mathrm{d}(0.5)$ and $\mathrm{d}(0.9)$ being $1.58 \mu \mathrm{m}, 11.17 \mu \mathrm{m}$ and $52.45 \mu \mathrm{m}$, respectively, as well as the volume of particles above $45 \mu \mathrm{m}$ was $10.47 \%$. The BET specific surface area of milled USSA was $14800 \mathrm{~m}^{2} / \mathrm{kg}$, which is a value close to the mean one found in the literature $\left(15100 \mathrm{~m}^{2} / \mathrm{kg}\right)(\mathrm{Cyr}$ et al. 2007). This significant fineness could be the outcome of the particle size reduction during the milling process, which enhances the reactivity of the pozzolanic materials (Cordeiro and Kurtis 2017). Furthermore, the density of milled USSA was $2.05 \mathrm{~g} / \mathrm{cm}^{3}$, which agrees with the range $\left(1.8-2.9 \mathrm{~g} / \mathrm{cm}^{3}\right)$ reported in the literature to SSA (Lynn et al. 2015). The $\mathrm{pH}$ of milled USSA did not presented significant variation after $1 \mathrm{~h}$ and $24 \mathrm{~h}$ in deionized water $\left(20^{\circ} \mathrm{C}\right)$, being the average value of 4.3 . Such acid aspect could be the outcome of sewage sludge from anaerobic wastewater treatment which present a pH range of 3.57-6.43 (Hanum et al. 2019). As shown in Fig. 4, the milled USSA presented irregular shape, porous and rough particles, being similar to the morphologies reported by other authors (Chen and Poon 2017; Garcés et al. 2008; Naamane et al. 2016). 
These physical characteristics of milled USSA lead to a hydroscopic behaviour, and a reduction of the mortar workability, consequently, when it is used as a replacement for cementitious materials (Chang et al. 2020). The chemical composition of milled USSA are summarised in Table 3. As can be seen, the ash was mainly composed of 32.72 wt. $\% \mathrm{SiO}_{2}, 20.72$ wt. $\% \mathrm{Al}_{2} \mathrm{O}_{3}$, and 11.27 wt. $\% \mathrm{Fe}_{2} \mathrm{O}_{3}$. These values are similar to those previously reported by Chen and Poon (Chen and Poon 2017). As reported in the literature, these components of SSA chemical composition are the outcome of the type of wastewater treatment apart from the effluent sources. $\mathrm{Al}_{2} \mathrm{O}_{3}$ and $\mathrm{Fe}_{2} \mathrm{O}_{3}$ usually come from alum and ferric salts used during the wastewater treatment (Tantawy et al. 2012; UNESCO World Water Assessment Programme 2017). The quartz content ( $\mathrm{SiO} 2)$, in case of the USSA herein studied, likely came from the soil particles carried by the rain evacuation in the urban drainage system, which is jointly treated with the wastewater in the wastewater treatment plant. Furthermore, the presence of quartz in the SSA chemical composition, in some cases, could be the outcome of the quartz sand application during the wastewater treatment as nucleation sites for secondary iron minerals (Ma et al. 2018). As plotted in Fig. 5, the crystalline phases identified in USSA were quartz $\left(\mathrm{SiO}_{2}\right.$, PDFcard\#331161), anhydrite $\left(\mathrm{CaSO}_{4}, \mathrm{PDF}\right.$ card\#371496) and hematite $\left(\mathrm{Fe}_{2} \mathrm{O}_{3}, \mathrm{PDF}\right.$ card\#130534). It is well-known that the reactivity of a pozzolanic material highly depends on its amorphous content, which is denoted in the XRD pattern of USSA by a slight deviation of the baseline in the $18^{\circ}-32^{\circ} 2 \theta$ range (Moraes et al. 2015). In the studied sample, the intensity of the peaks attributed to quartz masks the deviation from the baseline. The milled USSA presented $27.20 \%$ of insoluble residues, which implied that a great amount of $\mathrm{Al}_{2} \mathrm{O}_{3}$ was amorphous, as well as a significant part of $\mathrm{SiO}_{2}$, considering the low solubility of crystalline phases during to the insoluble residue test. The FTIR analyses performed on milled USSA are shown in Fig. 6. In agreement with the XRD results, the bands located at 1100, 1040, 671, 665, 611, and $455 \mathrm{~cm}^{-1}$ are attributed to Si-O-(Si, Al) vibrations (Criado et al. 2007; Tashima et al. 2017), and the Si-O double band at $796-778 \mathrm{~cm}^{-1}$ confirmed the presence of quartz (Criado et al. 2007). 
Table 3. Chemical composition of milled USSA (\%, in mass).

Fig. 4. SEM micrographs of milled USSA.

Fig. 5. XRD pattern of milled USSA.

204

Fig. 6. FTIR of milled USSA.

\section{Compressive strength development of the PC/USSA mortars}

The compressive strength results of the mortars containing 0 to $25 \mathrm{wt} . \%$ USSA, cured at $25{ }^{\circ} \mathrm{C}$ for 7,28 , and 90 days, are reported in Fig. 7. As observed, increasing the USSA content generally improved the compressive strength, whatever the curing age. Similarly, for a given USSA content, the compressive strength was increased over time. Commonly, the literature have usually reported that the compressive strength of PC-based mortar is decreased as the PC replacement level by SSA is increased (Baeza-Brotons et al. 2014; Chen et al. 2013; Cyr et al. 2007; Lynn et al. 2015). However, some authors reported compressive strength of mortars made with a 10-20 wt.\% SSA range in replacement of PC similar to one reached by a control mortar made with only PC (Chen and Poon 2017; Kappel et al. 2017). Chen and Poon (Chen and Poon 2017) observed that replacing up to $10 \mathrm{wt.} \%$ PC by SSA in mortars made with cementitious materials (PC + SSA), sand, water at a ratio of 1:2.75:0.484 did not reduce their compressive strength. Similarly, Kappel et al. (Kappel et al. 2017) reported comparable compressive strength values between mortars made with cementitious materials ( $\mathrm{PC}+\mathrm{SSA}$ ), sand, water at a ratio of 1:3.0:0.5 replacing 20\% PC by SSA and the reference mortar (only PC). Different compressive strength performance of the PC/SSAbased mortars reported in the literature are mainly due to the chemical composition of the SSA which could significantly vary depending on the sludge production and combustion method (Vouk et al. 2017) apart from the fineness that also affects its pozzolanic activity (Pan et al. 2003b). In the current study, the percentage of $\mathrm{Al}_{2} \mathrm{O}_{3}(20.72 \%)$ in USSA was superior to the average one (14.4\%) reported in the literature (Lynn et al. 2015), that could explain the reasonable reactivity of the ash. The compressive strength values of the mortars containing USSA cured for 90 days were in the range of 49.6-55.4 MPa, reaching values up to $11.5 \%$ higher than the one reached by the reference mortar (49.7 MPa after the same curing time). 
The relative compressive strength gain (CSGr) was calculated according to Eq. 1, previously described by Monzó et al. (Monzó et al. 1999). This value was used to measure the compressive strength (in \%) supplied by USSA to the mortars when compared with the hypothetical compressive strength given by an inert material (Monzó et al. 1999).

$$
C S G r=\left[\frac{R_{C}}{R_{C_{0}} \times w_{C} /\left(w_{C}+w_{U S S A}\right)}-1\right] \times 100
$$

Where $R_{C_{i}}$ is the compressive strength of the USSA-containing mortar, $R_{C_{0}}$ is the compressive strength of a reference mortar at the same curing age, $w_{C}$ is the weight of cement, and $w_{U S S A}$ is the weight of USSA. The obtained CSGr results are plotted in Fig. 8. As observed, the CSGr increased as the USSA content increased, whatever the curing age (7, 28, and 90 days), reaching a higher value (69.8\% for 25 wt.\% SSA) at short curing time (7 days). Positive CSGr values were always obtained, which denotes that USSA clearly contributed to the development of mortar compressive strength. Results agree with those previously reported by Monzó et al. (Monzó et al. 1999), who also observed an improvement of CSGr with increasing SSA content.

Fig. 7. Compressive Strength of the PC/USSA mortar samples cured from 7 to 90 days.

Fig. 8. Relative compressive strength gain registered by the PC/USSA mortars containing 5 wt. $\%$ to 25 wt.\% USSA, cured for 7, 28, and 90 days.

\section{TG/DTG analyses of CH/USSA pastes}

TG and DTG analyses were carried out on CH/USSA (3:7 and 1:1 mass ratio) pastes cured at $20{ }^{\circ} \mathrm{C}$ and 40 ${ }^{\circ} \mathrm{C}$. Two distinct $\mathrm{CH} / \mathrm{USSA}$ mass ratio and curing temperature conditions were evaluated to measure the extension of the pozzolanic reaction of USSA. Given that the consumption of the $\mathrm{Ca}(\mathrm{OH})_{2}$ determines the pozzolanic potential of USSA (Tironi et al. 2013), the $\mathrm{Ca}(\mathrm{OH})_{2}$ fixed $\left(\mathrm{CH}_{\text {Fixed }}\right)$ by the ash was evaluated. To do so, the Eq.2, previously proposed by Payá et al. (Payá et al. 2002), was used:

$$
C H_{\text {Fixed }}(\%)=\frac{\mathrm{CH}_{0}-\mathrm{CH}_{U S S A}}{C H_{0}} * 100
$$


where $\mathrm{CH}_{0}$ and $\mathrm{CH}_{U S S A}$ are the initial and final amounts of $\mathrm{Ca}(\mathrm{OH})_{2}$, respectively, in the $\mathrm{CH} / \mathrm{USSA}$ pastes.

The total mass loss and $\mathrm{CH}_{\text {Fixed }}$ values registered after the thermogravimetric analyses are reported in Table 4. The lowest amounts of fixed $\mathrm{Ca}(\mathrm{OH})_{2}$ were registered at the shortest curing time (3 days, $42.5 \% \pm 0.5$ ) with the $1: 1 \mathrm{CH} / \mathrm{USSA}$ proportion. On the contrary, $\mathrm{Ca}(\mathrm{OH})_{2}$ was totally consumed in the $3: 7 \mathrm{CH} / \mathrm{USSA}$ system cured for 28 days $\left(100 \% \mathrm{CH}_{\text {Fixed }}\right)$. Besides, in the system with a CH/USSA mass ratio of 1:1, the maximum content of $\mathrm{CH}_{\text {Fixed }}$ at $20{ }^{\circ} \mathrm{C}$ and $40{ }^{\circ} \mathrm{C}$ was $61.4 \%$ and $86.1 \%$, respectively. The obtained results confirmed the expected pozzolanic behaviour of USSA, given its fineness and chemical composition, previously described in the USSA characterisation section.

Three different regions were identified in the DTG curves of the CH/USSA pastes, which are plotted in Fig. 9. The first region $\mathrm{R}_{1}$, from $100^{\circ} \mathrm{C}$ to $180^{\circ} \mathrm{C}$, was associated with the mass loss due to the dehydration of calcium silicate hydrates (C-S-H) and ettringite $\left(\mathrm{C}_{3} \mathrm{~A} \cdot 3 \mathrm{CaSO}_{4} \cdot 32 \mathrm{H}_{2} \mathrm{O}-\mathrm{Aft}\right)$ (Payá et al. 2002). The second region $\mathrm{R}_{2}$, from $180^{\circ} \mathrm{C}$ to $300^{\circ} \mathrm{C}$, was attributed to the mass loss originated by the dehydration of calcium silicate aluminate hydrates (C-A-S-H) and calcium aluminate hydrates (C-A-H) (Payá et al. 2002; Shatat 2016). Finally, the third region $\mathrm{R}_{3}$, from $520^{\circ} \mathrm{C}$ to $600^{\circ} \mathrm{C}$, was assigned to dehydration of the $\mathrm{Ca}(\mathrm{OH})_{2}$ (Soriano et al. 2013).

Table 4. Mass loss registered after the TG/DTG analyses of the CH/USSA pastes $\left(\mathrm{R}_{1}, \mathrm{C}-\mathrm{S}-\mathrm{H}\right.$ and Aft; $\mathrm{R}_{2}$, C-A-S-H and C-A-H; $\mathrm{R}_{3}, \mathrm{Ca}(\mathrm{OH})_{2}$ dehydration) and the calculated percentage of fixed $\mathrm{Ca}(\mathrm{OH})_{2}$

$$
\left(\mathrm{CH}_{\text {Fixed }}\right) \text {. }
$$

As Fig. 9 shows, the band arising from $520^{\circ} \mathrm{C}$ to $600^{\circ} \mathrm{C}$ disappeared in the $\mathrm{CH} / \mathrm{USSA} 3: 7$ pastes after 28 curing days at $20^{\circ} \mathrm{C}$ or 3 curing days at $40^{\circ} \mathrm{C}$. This behaviour was explained by the consumption of $\mathrm{Ca}(\mathrm{OH})_{2}$ due to the pozzolanic reaction (Moraes et al. 2015; Payá et al. 2002; Soriano et al. 2013). The peak in the $\mathrm{R}_{3}$ region disappeared earlier in the specimen cured at $40^{\circ} \mathrm{C}$ than in that under $20^{\circ} \mathrm{C}$ which, as pointed out by Mirzahosseini and Riding (Mirzahosseini and Riding 2014), occurred because higher temperatures accelerate the pozzolanic reaction. The $\mathrm{Ca}(\mathrm{OH})_{2}$ dehydration band appeared in all of the $\mathrm{CH} / \mathrm{USSA} 1: 1$ specimens. Although its intensity reduced with higher temperatures or longer curing times, its presence indicated that higher amounts of USSA were required to consume all the $\mathrm{Ca}(\mathrm{OH})_{2}$ in the $\mathrm{CH} / \mathrm{USSA} 1: 1$ pastes. 
As previously reported in Table 3, USSA contained a high percentage of $\mathrm{Al}_{2} \mathrm{O}_{3}(20.72 \%)$, most probably due to the presence of different types of phyllosilicates in the sewage sludge. During the combustion process, these phyllosilicates decompose providing amorphous alumina that may react with $\mathrm{Ca}(\mathrm{OH})_{2}$ and reactive silica (also present in USSA) to produce aluminium hydrates. This would explain the broad band in the $\mathrm{R}_{2}$ region of the DTG curves, originated by the dehydration of C-A-H and C-A-S-H.

Fig. 9. DTG curves for the CH/USSA pastes prepared with a mass ratio of 3:7 and 1:1, cured at 20 and $40^{\circ} \mathrm{C}$ for $1,3,7$, and 28 days.

\section{TG/DTG analyses of PC/USSA pastes}

TG/DTG analyses were performed on PC/USSA pastes containing up to $25 \mathrm{wt} . \%$ USSA, and the results are summarised in Table 5 and Fig. 10. To assess the pozzolanic reaction of these pastes, the $\mathrm{CH}_{\text {Fixed }}$ was also calculated, according to the Eq. 3 proposed by Soriano et al. (Soriano et al. 2013).

$$
\mathrm{CH}_{\text {Fixed }}(\%)=\frac{\left.\left(\mathrm{CH}_{C} x \mathrm{C} \%\right)-\mathrm{CH}_{U S S A}\right)}{\left({ }^{\mathrm{C}} \mathrm{H}_{C} \mathrm{XC} \%\right)} * 100
$$

Where $\mathrm{CH}_{C}$ was the amount of $\mathrm{Ca}(\mathrm{OH})_{2}$ in the reference paste (0-USSA), $\mathrm{CH}_{S S A}$ was the amount of $\mathrm{Ca}(\mathrm{OH})_{2}$ in the PC/USSA pastes and $C \%$ was the proportion of $\mathrm{PC}$ in the mix.

As reported in Table 5, the 5-USSA (5 wt.\% USSA) paste cured for 7 days presented a negative $\mathrm{CH}_{\text {Fixed }}$ value. This is explained by the further hydration of the $\mathrm{PC}$ due to the significant amount of fine particles $(\mathrm{d}(0.5)=11.17 \mu \mathrm{m}$, Fig. 3) of USSA, that displayed nucleation site role, then yielding higher amount of available $\mathrm{Ca}(\mathrm{OH})_{2}$ (Jaturapitakkul et al. 2011; Khan et al. 2017; Soriano et al. 2016). Besides, the content of amorphous aluminosilicate phases provided by USSA in the 5-USSA specimen could be insufficient to consume a significant percentage of $\mathrm{Ca}(\mathrm{OH})_{2}$ produced in the Portland cement hydration. However, in the pastes prepared with the highest amount of USSA (25-USSA, 25 wt.\% USSA), the content of amorphous aluminosilicate phases supplied by USSA was noteworthy and, therefore, the pozzolanic effect was probably superior to the particle effect. This hypothesis was corroborated by the $\mathrm{CH}_{\text {Fixed }}$ values, since they reached a maximum of approximately $80 \%$ in the paste prepared with $25 \mathrm{wt} . \%$ USSA cured for both 7 and 90 days (25-USSA). Similar results were previously reported by Baeza-Brotons et al. (Baeza- 
Brotons et al. 2014), who also observed a progressive increase of the fixed $\mathrm{Ca}(\mathrm{OH})_{2}$ with increasing SSA contents, and reported a value of $33.28 \%$ when replacing $20 \mathrm{wt} . \%$ of PC by SSA.

For a given USSA content, the $\mathrm{CH}_{\text {Fixed }}$ value oscillated with the curing time. The hypothesis for such a phenomenon is the combination of the pozzolanic effect, which consumes $\mathrm{Ca}(\mathrm{OH})_{2}$, with the particle effect, which accelerates the PC hydration and thus, generates more $\mathrm{Ca}(\mathrm{OH})_{2}$. After 90 curing days, when the hydration of the Portland cement seems to be stable, the specimens with the highest USSA content consumed the highest amounts of $\mathrm{Ca}(\mathrm{OH})_{2}$.

The DTG curves of the PC/USSA pastes were also divided into three main regions, depending on the registered dehydration bands $\left(\mathrm{R}_{1}, \mathrm{R}_{2}\right.$ and $\left.\mathrm{R}_{3}\right)$. The mass loss in region $\mathrm{R}_{1}$ was linked to the formation of the C-S-H gel and ettringite, while the bands appearing in the $\mathrm{R}_{2}$ area denoted the dehydration of C-A-S-H and C-A-H. These products typically form after the hydration of PC and pozzolanic reactions (El-Diadamony et al. 2018; Jeon et al. 2018; Mastali et al. 2018). According to the DTG results, the mass loss in region $\mathrm{R}_{2}$ increased with the curing time and PC substitution, which is attributed to the reactivity of the alumina contained in USSA. The slight signal arising at $417{ }^{\circ} \mathrm{C}$ could originate from the dehydration of brucite $\left(\mathrm{Mg}(\mathrm{OH})_{2}\right)$, from the reactive magnesia $(\mathrm{MgO})$ present in USSA or PC (Imbabi et al. 2012; Zhang et al. 2015). In agreement with the fixed $\mathrm{Ca}(\mathrm{OH})_{2}$ results, the mass loss in the region $\mathrm{R}_{3}$ decreased with increasing USSA contents, which confirms that the $\mathrm{Ca}(\mathrm{OH})_{2}$ produced in the hydration of Portland cement was consumed during the pozzolanic reactions of USSA. The TG/DTG results are in line with the compressive strength evolution of the PC/USSA mortars shown in Fig. 7 since the mechanical properties also improved with increasing ash contents or longer curing times.

Fig. 10. DTG curves of PC/USSA pastes prepared with $100 \mathrm{wt} \%$ PC (0-USSA) and 5-25 wt.\% USSA (5USSA, 15-USSA, 25-USSA), cured at $25^{\circ} \mathrm{C}$ for 7,28 , and 90 days.

Table 5. Mass loss and percentage of fixed $\mathrm{Ca}(\mathrm{OH})_{2}\left(\mathrm{CH}_{\text {Fixed }}\right)$ registered during the TG/DTG tests of PC/USSA pastes. 
All PC/USSA pastes presented similar FTIR spectra, and the results are shown in Fig. 11. The band at 3639 $\mathrm{cm}^{-1}$ was assigned to the stretching vibrations of the structural O-H group in $\mathrm{Ca}(\mathrm{OH})_{2}$ (Moraes et al. 2015). In consonance with the TG/DTG results, this band tended to disappear with higher amounts of USSA or longer curing times, which corroborates the occurrence of the pozzolanic reaction. The bands at $3392 \mathrm{~cm}^{-1}$ and $1641 \mathrm{~cm}^{-1}$ were assigned to the stretching and bending vibration, respectively, of the $\mathrm{O}-\mathrm{H}$ group in the calcium aluminosilicate hydrate (C-A-S-H), generated by the hydration of PC and the pozzolanic reaction (Biricik and Sarier 2014; Kapeluszna et al. 2017; Kumar et al. 2018). The asymmetric stretching vibration of the Si-O-T ( $\mathrm{T}=\mathrm{Si}, \mathrm{Al}$ ) from the C-S-H and C-A-S-H gels appeared at $958 \mathrm{~cm}^{-1}$ (Kapeluszna et al. 2017). All of the spectra presented transmittance bands located at $1412 \mathrm{~cm}^{-1}$ and $874 \mathrm{~cm}^{-1}$, which were attributed to the asymmetric and stretching vibrations of the $\mathrm{C}-\mathrm{O}$ bonds in $\mathrm{CaCO}_{3}$ (Tantawy 2017). The signal at 1091 $\mathrm{cm}^{-1}$ was linked to the stretching vibration of the S-O bonds (Kumar et al. 2018; Tantawy 2017). This band also arose in all the specimens, mainly at early curing ages, and corroborated the presence of gypsum and the formation of ettringite during the PC hydration.

Fig. 11. FTIR spectra of the PC/USSA pastes prepared with 0 wt.\% USSA (a) 5 wt.\% USSA (b), 10 wt. $\%$ USSA (c) and 25 wt. $\%$ USSA (d); all of them cured at $25{ }^{\circ} \mathrm{C}$ for 7,28 , and 90 days.

\section{XRD analyses of PC/USSA pastes}

The XRD analyses were run on the reference paste (0-USSA) and for that containing $25 \mathrm{wt} . \%$ USSA (25USSA), which presented the highest compressive strength (Fig. 7) and fixed $\mathrm{Ca}(\mathrm{OH})_{2}$ values (Table 6). The XRD patterns are presented in Fig. 12. As observed, signals due to the formation of ettringite $\left(\mathrm{Ca}_{6} \mathrm{Al}_{2}\left(\mathrm{SO}_{4}\right)_{3}(\mathrm{OH})_{12} .26 \mathrm{H}_{2} \mathrm{O}\right.$, PDFCard\#00411451) arose in both spectra (0-USSA and 25-USSA), mainly at short curing ages. Peaks associated with the presence of monosulfate $\left(\mathrm{Ca}_{4} \mathrm{Al}_{2} \mathrm{SO}_{10} \cdot 12 \mathrm{H}_{2} \mathrm{O}\right.$, PDFCard\#180275) were also distinguished after 90 curing days. These could have resulted from the transformation of ettringite or have directly formed from the reaction of $\mathrm{Ca}_{3} \mathrm{Al}_{2} \mathrm{O}_{6}\left(\mathrm{C}_{3} \mathrm{~A}\right)$ in the presence of small amounts of gypsum (Christensen et al. 2004). The peaks attributed to calcite $\left(\mathrm{CaCO}_{3}\right.$, PDFCard\#050586), which arose in both samples, were associated with its presence in PC or slight carbonation of the pastes. 
The brucite $\left(\mathrm{Mg}(\mathrm{OH})_{2}\right.$, PDFCard\#16747) and gypsum $\left(\mathrm{CaSO}_{4}\right.$, PDFcard\#371496) peaks identified in the 25-USSA XRD pattern might be due to the presence of $\mathrm{MgO}$ and $\mathrm{SO}_{3}$ in the original USSA (Table 3). Signals originated by carboaluminate phases $\left(\mathrm{Ca}_{4} \mathrm{Al}_{2} \mathrm{O}_{6} \mathrm{CO}_{3} .11 \mathrm{H}_{2} \mathrm{O}\right.$, PDFCard\#410219) also arose in both specimens, 0-USSA and 25-USSA, most probably resulting from the reaction between anhydrous calcium aluminate and $\mathrm{CaCO}_{3}$ (Segui et al. 2012). The main portlandite peaks $\left(\mathrm{Ca}(\mathrm{OH})_{2}\right.$, PDFCard\#040733) in the XRD pattern of the 25-USSA paste decreased over time, confirming the consumption of $\mathrm{Ca}(\mathrm{OH})_{2}$ due to the USSA pozzolanic reactions. Furthermore, a broader diffusive halo was observed in the XRD pattern of the 25-USSA paste over time, which means a larger amount of amorphous hydrated phases over time, endorsing the occurrence of the pozzolanic reaction. The broad diffusive halo observed in the XRD patterns, for a given curing age, was more noteworthy in the 25-USSA paste than in the reference sample, which confirmed the presence of a higher amount of amorphous phases after partially replacing PC by USSA, and thus a greater compressive strength of the sample 25-USSA, in line with the compressive strength results.

Fig. 12. XRD spectra of the reference paste (0 USSA - black line) and the PC/USSA paste prepared with 25 wt.\% USSA (25 USSA - red line); samples were cured at room temperature for (a) 7 days, (b) 28 days, and (c) 90 days.

\section{SEM analyses}

The SEM analyses were conducted on 0 USSA and 25 USSA pastes cured for 28 and 90 days. As shown in Fig. 13, all samples exhibited a dense microstructure with similar reactions products, such as hydrated gehlenite, C-A-S-H, C-S-H or ettringite. All these products were previously identified by TG/DTG, FTIR or XRD analyses and typically formed during the cement hydration or pozzolanic reaction.

Fig. 13. SEM micrographs of the 0-USSA paste cured for 28 (a) and 90 days (b), and the 25-USSA paste cured for 28 (c) and 90 days (d). Ettringite (ET), hydrated gehlenite (GEH), and C-S-H gels (C-S-H). 
A simple and economic uncontrolled-combustion process was used to produce sewage sludge ash (USSA). The reactivity of this ash was investigated, with the following results:

- The chemical composition of USSA was similar to that reported in the literature for the SSA obtained from controlled-combustion processes.

- The USSA exhibited a high $\mathrm{Al}_{2} \mathrm{O}_{3}$ content (20.72 wt.\%), which was attributed to the presence of phyllosilicates in the sewage sludge, that yielded amorphous alumina after their thermal decomposition.

- The pozzolanic reaction of USSA with $\mathrm{Ca}(\mathrm{OH})_{2}$ liberated during the hydration of $\mathrm{PC}$ originated hydrated compounds that contributed to improving the mechanical development of the PC/USSA mortars. For a given curing age, PC/USSA mortars exhibited better compressive strength values than the reference mortar (0 wt.\% USSA).

- A maximum relative compressive strength gain of $69.8 \%$ was registered, which was provided by the mortar prepared with $25 \mathrm{wt} . \%$ USSA, cured at $25^{\circ} \mathrm{C}$ for 7 days.

This research adds knowledge to the existing studies, which generally used sewage sludge ash produced under temperature and time-controlled processes, in technological incineration plants. The novelty is based on: a) the uncontrolled-combustion of the sewage sludge can generate ash with a low loss on ignition; and b) the obtained ash presents good pozzolanic activity, improving significantly the mechanical development of Portland cement-based mortar when used as supplementary cementing material. This study may encourage further investigations, aiming to promote new solutions to manage the waste generated in wastewater treatment plants which, due to economic and technological issues, is currently being deposited mainly in landfills.

\section{Acknowledgements}

This research was financed in part by the Coordenação de Aperfeiçoamento de Pessoal de Nível Superior Brasil (Capes) - Finance Code 001, and Conselho Nacional de Desenvolvimento Científico e Tecnológico (CNPq) (processo $\mathrm{n}^{\circ} 309015 / 2015-4$ and processo $\mathrm{n}^{\circ} 478057 / 2013-0$ ). Thanks are go to the Scanning 
Electron Microscopy Service of FEIS/UNESP, Serviço Municipal Autônomo de Água e Esgoto (SEMAE) from the São José do Rio Preto city - SP, Brazil.

\section{References}

Abuşoğlu, A., Özahi, E., İhsan Kutlar, A., and Al-jaf, H. (2017). "Life cycle assessment (LCA) of digested sewage sludge incineration for heat and power production." Journal of Cleaner Production, Elsevier, 142, 1684-1692.

Associação Brasileira de Normas Técnicas - ABNT (2019), NBR 7215:2019 - Portland cement: Determination of compressive strength of cylindrical test specimens, Rio de Janeiro, $12 \mathrm{p}$.

Asociación Española de Normalización (2014), UNE-EN 196-2:2014 - Method of testing cement - Part 2, Chemical analysis of cement, 76 p.

Baeza-Brotons, F., Garcés, P., Payá, J., and Saval, J. M. (2014). "Portland cement systems with addition of sewage sludge ash. Application in concretes for the manufacture of blocks." Journal of Cleaner Production, 82, 112-124.

Biricik, H., and Sarier, N. (2014). "Comparative study of the characteristics of nano silica -, silica fume - and fly ash - incorporated cement mortars." Materials Research, 17(3), 570-582.

Chang, Z., Long, G., Zhou, J. L., and Ma, C. (2020). "Valorization of sewage sludge in the fabrication of construction and building materials: A review." Resources, Conservation and Recycling, Elsevier B.V.

Chen, M., Blanc, D., Gautier, M., Mehu, J., and Gourdon, R. (2013). "Environmental and technical assessments of the potential utilization of sewage sludge ashes (SSAs) as secondary raw materials in construction." Waste management (New York, N.Y.), 33(5), $1268-75$.

Chen, Z., and Poon, C. S. (2017). "Comparative studies on the effects of sewage sludge ash and 
fly ash on cement hydration and properties of cement mortars." Construction and Building Materials, Elsevier Ltd, 154, 791-803.

Christensen, A. N., Jensen, T. R., and Hanson, J. C. (2004). "Formation of ettringite, Ca6Al2(SO4)3(OH)12·26H2O, AFt, and monosulfate, Ca4Al2O6(SO4) 14H2O, AFm-14, in hydrothermal hydration of Portland cement and of calcium aluminum oxide-calcium sulfate dihydrate mixtures studied by in situ synchrotron X-ray powder.” Journal of Solid State Chemistry, Academic Press, 177(6), 1944-1951.

Cordeiro, G. C., and Kurtis, K. E. (2017). "Effect of mechanical processing on sugar cane bagasse ash pozzolanicity." Cement and Concrete Research, Pergamon, 97, 41-49.

Criado, M., Fernández-Jiménez, A., and Palomo, A. (2007). “Alkali activation of fly ash: Effect of the $\mathrm{SiO} 2 / \mathrm{Na} 2 \mathrm{O}$ ratio: Part I: FTIR study." Microporous and Mesoporous Materials, Elsevier, 106(1-3), 180-191.

Cyr, M., Coutand, M., and Clastres, P. (2007). "Technological and environmental behavior of sewage sludge ash (SSA) in cement-based materials." Cement and Concrete Research, 37(8), 1278-1289.

Donatello, S., and Cheeseman, C. R. (2013). "Recycling and recovery routes for incinerated sewage sludge ash (ISSA): a review." Waste management (New York, N.Y.), 33(11), 232840.

Donatello, S., Freeman-Pask, A., Tyrer, M., and Cheeseman, C. R. (2010). "Effect of milling and acid washing on the pozzolanic activity of incinerator sewage sludge ash." Cement and Concrete Composites, 32(1), 54-61.

Dyer, T. D., Halliday, J. E., and Dhir, R. K. (2011). "Hydration Chemistry of Sewage Sludge Ash Used as a Cement Component." Journal of Materials in Civil Engineering, American Society of Civil Engineers, 23(5), 648-655.

El-Diadamony, H., Amer, A. A., Sokkary, T. M., and El-Hoseny, S. (2018). "Hydration and 
Garcés, P., Pérez Carrión, M., García-Alcocel, E., Payá, J., Monzó, J., and Borrachero, M. V. (2008). "Mechanical and physical properties of cement blended with sewage sludge ash." Waste management (New York, N.Y.), 28(12), 2495-502.

Gastaldini, A. L. G., Hengen, M. F., Gastaldini, M. C. C., do Amaral, F. D., Antolini, M. B., and Coletto, T. (2015). "The use of water treatment plant sludge ash as a mineral addition." Construction and Building Materials, 94, 513-520.

Hanum, F., Yuan, L. C., Kamahara, H., Aziz, H. A., Atsuta, Y., Yamada, T., and Daimon, H. (2019). “Treatment of Sewage Sludge Using Anaerobic Digestion in Malaysia: Current State and Challenges." Frontiers in Energy Research, Frontiers Media S.A., 7(MAR), 19.

He, P., Poon, C. S., and Tsang, D. C. W. (2017). "Using incinerated sewage sludge ash to improve the water resistance of magnesium oxychloride cement (MOC).” Construction and Building Materials, Elsevier Ltd, 147, 519-524.

Imbabi, M. S., Carrigan, C., and McKenna, S. (2012). "Trends and developments in green cement and concrete technology." International Journal of Sustainable Built Environment, 1(2), 194-216.

International Organization for Standardization (2010), ISO 9277:2010 - Determination of the specific surface area of solids by gas adsorption - BET method, $24 \mathrm{p}$.

Jaturapitakkul, C., Tangpagasit, J., Songmue, S., and Kiattikomol, K. (2011). "Filler effect and pozzolanic reaction of ground palm oil fuel ash." Construction and Building Materials, Elsevier, 25(11), 4287-4293.

Jeon, D., Yum, W. S., Jeong, Y., and Oh, J. E. (2018). "Properties of quicklime(CaO)-activated Class F fly ash with the use of CaCl2." Cement and Concrete Research, Pergamon, 111, 147-156. 
Kapeluszna, E., Kotwica, Ł., Różycka, A., and Gołek, Ł. (2017). “Incorporation of Al in C-A-S$\mathrm{H}$ gels with various $\mathrm{Ca} / \mathrm{Si}$ and $\mathrm{Al} / \mathrm{Si}$ ratio: Microstructural and structural characteristics with DTA/TG, XRD, FTIR and TEM analysis." Construction and Building Materials, Elsevier, $155,643-653$.

Kappel, A., Ottosen, L. M., and Kirkelund, G. M. (2017). "Colour, compressive strength and workability of mortars with an iron rich sewage sludge ash." Construction and Building Materials, Elsevier, 157, 1199-1205.

Kelessidis, A., and Stasinakis, A. S. (2012). "Comparative study of the methods used for treatment and final disposal of sewage sludge in European countries." Waste Management, Elsevier Ltd, 32(6), 1186-1195.

Khan, M. N. N., Jamil, M., Karim, M. R., Zain, M. F. M., and Kaish, A. B. M. A. (2017). "Filler effect of pozzolanic materials on the strength and microstructure development of mortar." KSCE Journal of Civil Engineering, Korean Society of Civil Engineers, 21(1), 274-284.

Kliopova, I., and Makarskienè, K. (2015). "Improving material and energy recovery from the sewage sludge and biomass residues.” Waste management (New York, N.Y.), 36, 269-76.

Krüger, O., and Adam, C. (2015). "Recovery potential of German sewage sludge ash." Waste management (New York, N.Y.).

Kumar, S., Djobo, J. N. Y., Kumar, A., and Kumar, S. (2018). "Size fractionation of brown fly ash: utilisation of grey fraction as a pozzolanic material in blended cement." European Journal of Environmental and Civil Engineering, Taylor \& Francis, 8189, 1-16.

Li, J. S., Guo, M. Z., Xue, Q., and Poon, C. S. (2017). "Recycling of incinerated sewage sludge ash and cathode ray tube funnel glass in cement mortars." Journal of Cleaner Production, Elsevier Ltd, 152, 142-149.

Li, J., Zhou, Y., Wang, Q., Xue, Q., and Poon, C. S. (2019). "Development of a Novel Binder Using Lime and Incinerated Sewage Sludge Ash to Stabilize and Solidify Contaminated 
Lin, D.-F., Luo, H.-L., and Zhang, S.-W. (2007). "Effects of Nano-SiO2 On Tiles Manufactured with Clay and Incinerated Sewage Sludge Ash." Journal of Materials in Civil Engineering, American Society of Civil Engineers, 19(10), 801-808.

Liu, G., Yang, Z., Chen, B., Zhang, J., Liu, X., Zhang, Y., Su, M., and Ulgiati, S. (2014). "Scenarios for sewage sludge reduction and reuse in clinker production towards regional eco-industrial development: a comparative emergy-based assessment." Journal of Cleaner Production.

Lynn, C. J., Dhir, R. K., Ghataora, G. S., and West, R. P. (2015). "Sewage sludge ash characteristics and potential for use in concrete." Construction and Building Materials, 98, 767-779.

Ma, Y., Wang, H., Song, Y., Wu, Y., and Guo, Z. (2018). “The Synthesis of Secondary Iron Minerals Induced by Quartz Sand during the Bioleaching Process Improves the Dewaterability of Municipal Sewage Sludge.” Minerals, MDPI AG, 8(10), 419.

Mastali, M., Dalvand, A., Sattarifard, A. R., Abdollahnejad, Z., Nematollahi, B., Sanjayan, J. G., and Illikainen, M. (2018). "A comparison of the effects of pozzolanic binders on the hardened-state properties of high-strength cementitious composites reinforced with waste tire fibers." Composites Part B: Engineering, Elsevier.

Mirzahosseini, M., and Riding, K. A. (2014). "Effect of curing temperature and glass type on the pozzolanic reactivity of glass powder." Cement and Concrete Research, Pergamon, 58, 103111.

Monzó, J., Payá, J., Borrachero, M. ., and Peris-Mora, E. (1999). “Mechanical behavior of mortars containing sewage sludge ash (SSA) and Portland cements with different tricalcium aluminate content." Cement and Concrete Research, 29(1), 87-94. 
Monzó, J., Payá, J., Borrachero, M. V, and Girbés, I. (2003). "Reuse of sewage sludge ashes (SSA) in cement mixtures: the effect of SSA on the workability of cement mortars." Waste management (New York, N.Y.), 23(4), 373-81.

Moraes, J. C. B., Akasaki, J. L., Melges, J. L. P., Monzó, J., Borrachero, M. V., Soriano, L., Payá, J., and Tashima, M. M. (2015). "Assessment of sugar cane straw ash (SCSA) as pozzolanic material in blended Portland cement: Microstructural characterization of pastes and mechanical strength of mortars." Construction and Building Materials, 94, 670-677.

Moraes, J. C. B., Melges, J. L. P., Akasaki, J. L., Tashima, M. M., Soriano, L., Monzó, J., Borrachero, M. V., and Payá, J. (2016). "Pozzolanic Reactivity Studies on a BiomassDerived Waste from Sugar Cane Production: Sugar Cane Straw Ash (SCSA)." ACS Sustainable Chemistry and Engineering, 4(8), 4273-4279.

Naamane, S., Rais, Z., and Taleb, M. (2016). "The effectiveness of the incineration of sewage sludge on the evolution of physicochemical and mechanical properties of Portland cement." Construction and Building Materials, 112, 783-789.

Oliva, M., Vargas, F., and Lopez, M. (2019). "Designing the incineration process for improving the cementitious performance of sewage sludge ash in Portland and blended cement systems.” Journal of Cleaner Production, Elsevier, 223, 1029-1041.

Pan, S.-C., Lin, C.-C., and Tseng, D.-H. (2003a). "Reusing sewage sludge ash as adsorbent for copper removal from wastewater.” Resources, Conservation and Recycling, 39(1), 79-90.

Pan, S.-C., Tseng, D.-H., Lee, C.-C., and Lee, C. (2003b). "Influence of the fineness of sewage sludge ash on the mortar properties." Cement and Concrete Research, 33(11), 1749-1754.

Payá, J., Monzó, J., Borrachero, M. V., Díaz-Pinzón, L., and Ordóñez, L. M. (2002). “Sugar-cane bagasse ash (SCBA): studies on its properties for reusing in concrete production." Journal of Chemical Technology \& Biotechnology, Wiley-Blackwell, 77(3), 321-325.

Perez Carrion, M. T., Baeza Brotons, F., Garcés, P., Galao Malo, O., and Paya Bernabeu, J. 

(2013). "Potencial use of Sewage Sludge Ash as a Fine Aggregate Replacement in Precast Concrete Blocks.” Dyna-Colombia, 80(179), 142-150.

Segui, P., Aubert, J. E., Husson, B., and Measson, M. (2012). "Characterization of wastepaper sludge ash for its valorization as a component of hydraulic binders." Applied Clay Science, $57,79-85$.

Shatat, M. R. (2016). "Hydration behavior and mechanical properties of blended cement containing various amounts of rice husk ash in presence of metakaolin." Arabian Journal of Chemistry, Elsevier, 9, S1869-S1874.

Smol, M., Kulczycka, J., Henclik, A., Gorazda, K., and Wzorek, Z. (2015). "The possible use of sewage sludge ash (SSA) in the construction industry as a way towards a circular economy." Journal of Cleaner Production, 95, 45-54.

Soriano, L., Monzó, J., Bonilla, M., Tashima, M. M., Payá, J., and Borrachero, M. V. (2013). "Effect of pozzolans on the hydration process of Portland cement cured at low temperatures." Cement and Concrete Composites, Elsevier Ltd, 42, 41-48.

Soriano, L., Payá, J., Monzó, J., Borrachero, M. V., and Tashima, M. M. (2016). "High strength mortars using ordinary Portland cement-fly ash-fluid catalytic cracking catalyst residue ternary system (OPC/FA/FCC).” Construction and Building Materials, Elsevier Ltd, 106, 228-235.

Tantawy, M. A. (2017). "Effect of High Temperatures on the Microstructure of Cement Paste." Journal of Materials Science and Chemical Engineering, Scientific Research Publishing, 05(11), 33-48.

Tantawy, M. a., El-Roudi, a. M., Abdalla, E. M., and Abdelzaher, M. A. (2012). "Evaluation of the Pozzolanic Activity of Sewage Sludge Ash.” ISRN Chemical Engineering, Hindawi, 2012(iv), 1-8.

Tarrago, M., Garcia-Valles, M., Aly, M. H., and Mart??nez, S. (2017). "Valorization of sludge 

from a wastewater treatment plant by glass-ceramic production." Ceramics International, Elsevier, 43(1), 930-937.

Tashima, M. M., Reig, L., Santini, M. A., B Moraes, J. C., Akasaki, J. L., Payá, J., Borrachero, M. V., and Soriano, L. (2017). "Compressive Strength and Microstructure of AlkaliActivated Blast Furnace Slag/Sewage Sludge Ash (GGBS/SSA) Blends Cured at Room Temperature." Waste and Biomass Valorization, Springer Netherlands, 8(5), 1441-1451.

Tironi, A., Trezza, M. A., Scian, A. N., and Irassar, E. F. (2013). “Assessment of pozzolanic activity of different calcined clays." Cement and Concrete Composites, 37, 319-327.

UNESCO World Water Assessment Programme. (2017). Wastewater. The Untapped Ressource. The United Nations World Water Development Report. Wastewater. The Untapped Resource., France.

Vouk, D., Nakic, D., Stirmer, N., and Cheeseman, C. R. (2017). "Use of sewage sludge ash in cementitious materials." Reviews on Advanced Materials Science, 49(2), 158-170.

Wang, L., Skjevrak, G., Hustad, J. E., and Grønli, M. G. (2012). "Sintering characteristics of sewage sludge ashes at elevated temperatures." Fuel Processing Technology, 96, 88-97.

Xin-gang, Z., Gui-wu, J., Ang, L., and Yun, L. (2016). "Technology, cost, a performance of waste-to-energy incineration industry in China." Renewable and Sustainable Energy Reviews, Pergamon, 55, 115-130.

Yusuf, R. O., Noor, Z. Z., Moh', N. A., Moh', d F., Din, D., and Abba, A. H. (2012). "Use of sewage sludge ash (SSA) in the production of cement and concrete - a review." International Journal of Global Environmental Issues, Elsevier B.V., 12(2/3/4), 214.

Zhang, Y., Sun, Y., Xu, K., Yuan, Z., Zhang, J., Chen, R., Xie, H., and Cheng, R. (2015). "Brucite modified epoxy mortar binders: Flame retardancy, thermal and mechanical characterization.” Construction and Building Materials, Elsevier, 93, 1089-1096.

Zhou, Y., Li, J., Lu, J., Cheeseman, C., and Poon, C. S. (2019). "Recycling incinerated sewage 
Table 1. Mix proportion of the PC/USSA mortars.

\begin{tabular}{cccccc}
\hline \multirow{2}{*}{ Mortar samples } & PC & USSA & w/cm & s/cm & \\
\cline { 2 - 4 }$\%$ mass & (mass ratio) & \\
\hline 0-USSA & 100 & 0 & & & \\
5-USSA & 95 & 5 & & & \\
10-USSA & 90 & 10 & & & Moisture room \\
15-USSA & 85 & 15 & 0.5 & 2 & (relative humidity $\approx 95 \%, 25^{\circ} \mathrm{C}$ ) \\
20-USSA & 80 & 20 & & & \\
25-USSA & 75 & 25 & & & \\
\hline
\end{tabular}

620

Table 2. Particle size, BET specific surface area, specific gravity and $\mathrm{pH}$ of USSA.

\begin{tabular}{ccc} 
& Milled USSA & Unmilled USSA \\
\hline Mean diameter & $20.28 \mu \mathrm{m}$ & $199.41 \mu \mathrm{m}$ \\
\hline $\mathrm{d}(0.1)$ & $1.58 \mu \mathrm{m}$ & $4.43 \mu \mathrm{m}$ \\
\hline $\mathrm{d}(0.5)$ & $11.17 \mu \mathrm{m}$ & $95.19 \mu \mathrm{m}$ \\
\hline $\mathrm{d}(0.9)$ & $52.45 \mu \mathrm{m}$ & $539.70 \mu \mathrm{m}$ \\
\hline Particle above $45 \mu \mathrm{m}$ & $10.47 \%$ & - \\
\hline BET specific surface area & $14800 \mathrm{~m}^{2} / \mathrm{kg}$ & - \\
\hline Specific gravity & $2.05 \mathrm{~g} / \mathrm{cm}^{3}$ & - \\
\hline $\mathrm{pH}$ & 4.13 & - \\
\hline
\end{tabular}

Table 3. Chemical composition of milled USSA (\%, in mass).

\begin{tabular}{ccccccccccccc}
\hline Major Oxides & $\mathrm{SiO}_{2}$ & $\mathrm{Al}_{2} \mathrm{O}_{3}$ & $\mathrm{Fe}_{2} \mathrm{O}_{3}$ & $\mathrm{P}_{2} \mathrm{O}_{5}$ & $\mathrm{CaO}$ & $\mathrm{SO}_{3}$ & $\mathrm{TiO}_{2}$ & $\mathrm{MgO}$ & $\mathrm{K}_{2} \mathrm{O}$ & $\mathrm{Na}_{2} \mathrm{O}$ & $\mathrm{Others}$ & LOI \\
\hline USSA & 38.28 & 20.72 & 11.27 & 7.28 & 5.51 & 4.18 & 3.73 & 1.91 & 0.73 & 0.70 & 1.97 & 3.72 \\
\hline
\end{tabular}

624 
632

1:1

\begin{tabular}{|c|c|c|c|c|c|c|c|}
\hline \multirow{2}{*}{$\begin{array}{l}\mathrm{CH} / \mathrm{USSA} \text {, } \\
\text { mass ratio }\end{array}$} & \multirow{2}{*}{$\begin{array}{l}\mathrm{T}, \\
{ }^{\circ} \mathrm{C}\end{array}$} & \multirow{2}{*}{$\begin{array}{l}\text { Curing } \\
\text { age, } \\
\text { days }\end{array}$} & \multicolumn{3}{|c|}{ Mass loss $(\%)$} & \multirow{2}{*}{$\begin{array}{c}\text { Total mass loss } \\
(\%) \\
\left(35-600^{\circ} \mathrm{C}\right) \\
\end{array}$} & \multirow[b]{2}{*}{$\mathrm{CH}_{\text {Fixed }}(\%)$} \\
\hline & & & $\begin{array}{c}\mathrm{R}_{1} \\
\left(100-180^{\circ} \mathrm{C}\right) \\
\end{array}$ & $\begin{array}{c}\mathrm{R}_{2} \\
\left(180-300^{\circ} \mathrm{C}\right) \\
\end{array}$ & $\begin{array}{c}\mathrm{R}_{3} \\
\left(520-600^{\circ} \mathrm{C}\right) \\
\end{array}$ & & \\
\hline \multirow{7}{*}{$3: 7$} & \multirow{3}{*}{20} & 3 & 1.5 & 5.4 & 2.0 & 11.3 & 70.6 \\
\hline & & 7 & 1.9 & 5.9 & 1.5 & 11.7 & 78.7 \\
\hline & & 28 & 3.0 & 8.4 & - & 14.4 & 100 \\
\hline & \multirow{4}{*}{40} & 1 & 1.7 & 4.5 & 2.2 & 11.0 & 68.1 \\
\hline & & 3 & 2.2 & 5.5 & 0.1 & 11.4 & 98.4 \\
\hline & & 7 & 2.8 & 6.5 & - & 12.4 & 100 \\
\hline & & 28 & 3.4 & 6.3 & - & 13.3 & 100 \\
\hline \multirow{7}{*}{$1: 1$} & \multirow{3}{*}{20} & 3 & 1.5 & 4.6 & 6.6 & 14.7 & 42.5 \\
\hline & & 7 & 1.9 & 4.9 & 6.4 & 15.5 & 44.4 \\
\hline & & 28 & 2.3 & 7.0 & 4.4 & 17.2 & 61.4 \\
\hline & \multirow{4}{*}{40} & 1 & 1.5 & 4.8 & 6.5 & 14.8 & 43.5 \\
\hline & & 3 & 2.2 & 5.5 & 4.9 & 15.2 & 57.6 \\
\hline & & 7 & 2.8 & 5.9 & 3.6 & 15.8 & 68.7 \\
\hline & & 28 & 2.5 & 5.9 & 1.6 & 14.5 & 86.1 \\
\hline
\end{tabular}

Table 5. Mass loss and percentage of fixed $\mathrm{Ca}(\mathrm{OH})_{2}\left(\mathrm{CH}_{\text {Fixed }}\right)$ registered during the TG/DTG tests of PC/USSA pastes.

\begin{tabular}{|c|c|c|c|c|c|c|}
\hline \multirow[b]{2}{*}{ Curing days } & \multirow[b]{2}{*}{ Specimens } & \multicolumn{3}{|c|}{ Mass loss $(\%)$} & \multirow{2}{*}{$\begin{array}{c}\text { Total loss } \\
(\%) \\
\left(35-600{ }^{\circ} \mathrm{C}\right)\end{array}$} & \multirow{2}{*}{$\begin{array}{c}\mathrm{CH}_{\text {Fixed }} \\
(\%)\end{array}$} \\
\hline & & $\begin{array}{c}\mathrm{R}_{1} \\
\left(100-180^{\circ} \mathrm{C}\right) \\
\end{array}$ & $\begin{array}{c}\mathrm{R}_{2} \\
\left(180-300^{\circ} \mathrm{C}\right)\end{array}$ & $\begin{array}{c}\mathrm{R}_{3} \\
\left(520-600^{\circ} \mathrm{C}\right) \\
\end{array}$ & & \\
\hline \multirow{4}{*}{7} & 0-USSA & 6.8 & 3.6 & 1.7 & 16.0 & - \\
\hline & 5-USSA & 8.1 & 3.9 & 1.7 & 18.1 & -9.2 \\
\hline & 15-USSA & 8.6 & 4.4 & 0.8 & 18.1 & 44.2 \\
\hline & 25-USSA & 8.7 & 4.2 & 0.2 & 17.7 & 80.2 \\
\hline \multirow{4}{*}{28} & 0-USSA & 6.3 & 3.5 & 1.2 & 14.7 & - \\
\hline & 5-USSA & 8.1 & 3.8 & 1.0 & 16.9 & 9.0 \\
\hline & 15-USSA & 7.5 & 4.0 & 0.4 & 15.9 & 60.8 \\
\hline & 25-USSA & 10.6 & 4.9 & 0.4 & 21.1 & 58.9 \\
\hline \multirow{4}{*}{90} & 0-USSA & 5.2 & 4.0 & 1.9 & 15.7 & - \\
\hline & 5-USSA & 5.8 & 4.9 & 1.7 & 17.5 & 5.8 \\
\hline & 15-USSA & 5.1 & 5.9 & 1.0 & 18.0 & 38.9 \\
\hline & 25-USSA & 6.1 & 6.1 & 0.3 & 17.7 & 79.8 \\
\hline
\end{tabular}




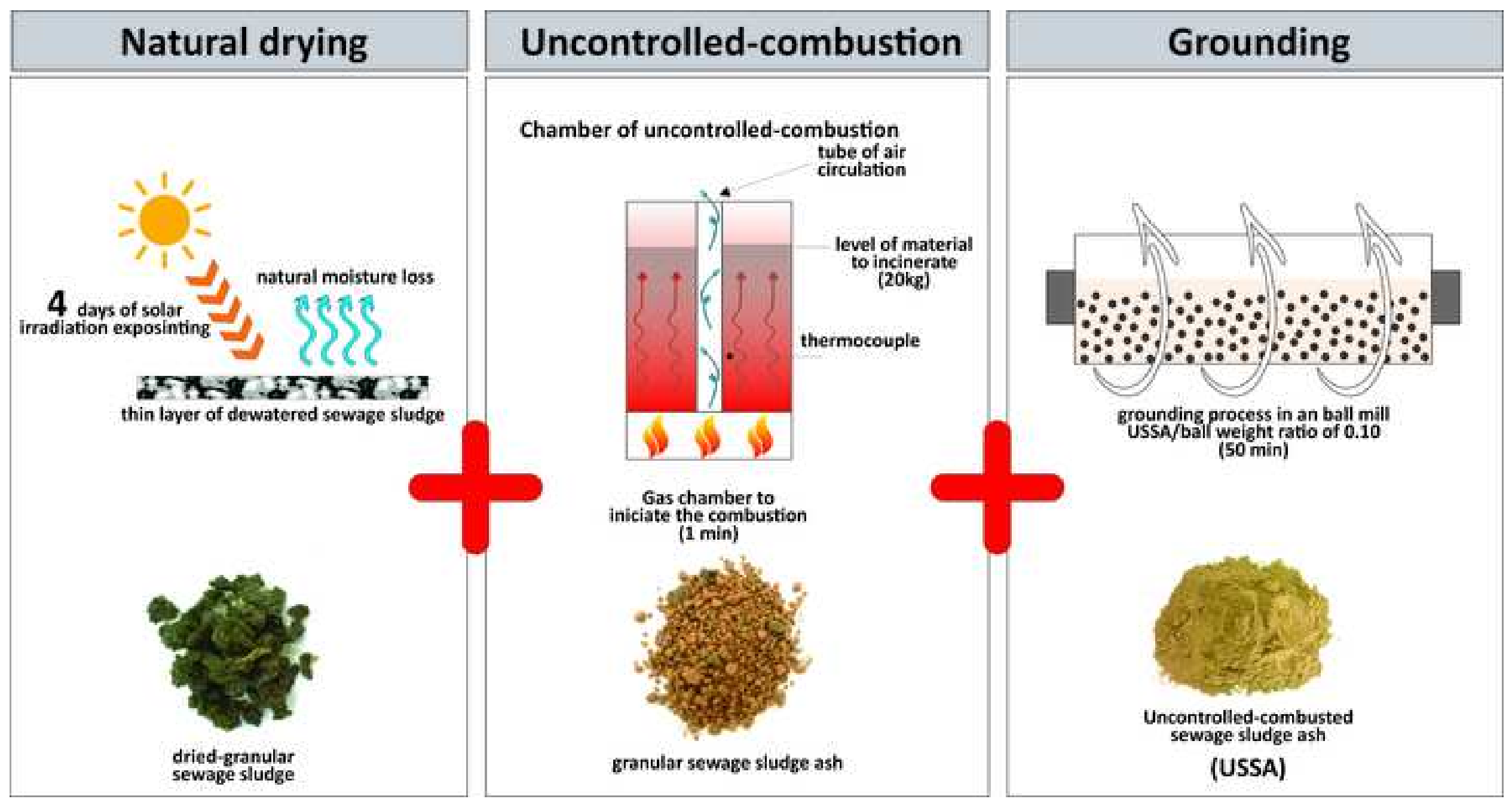




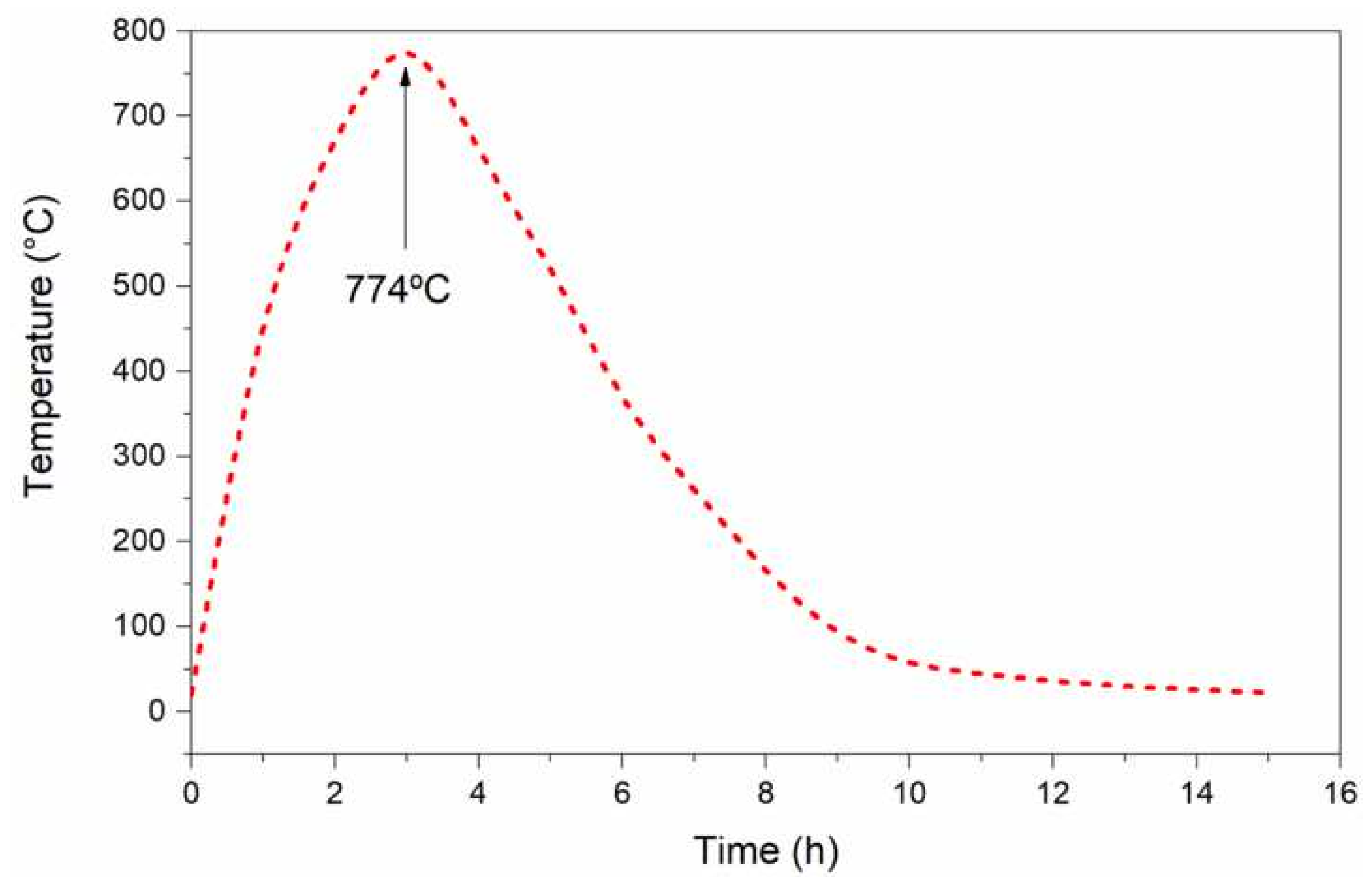




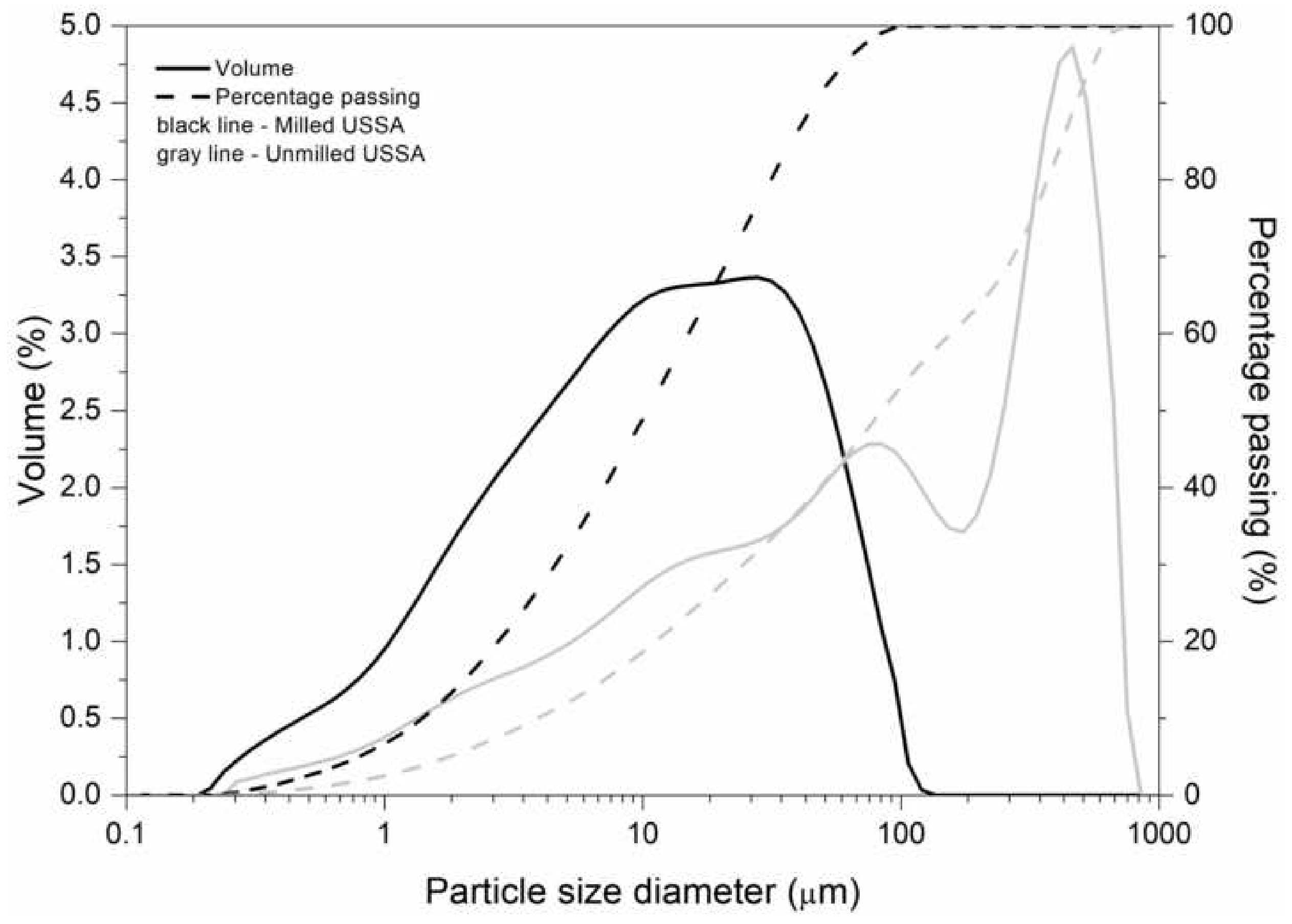




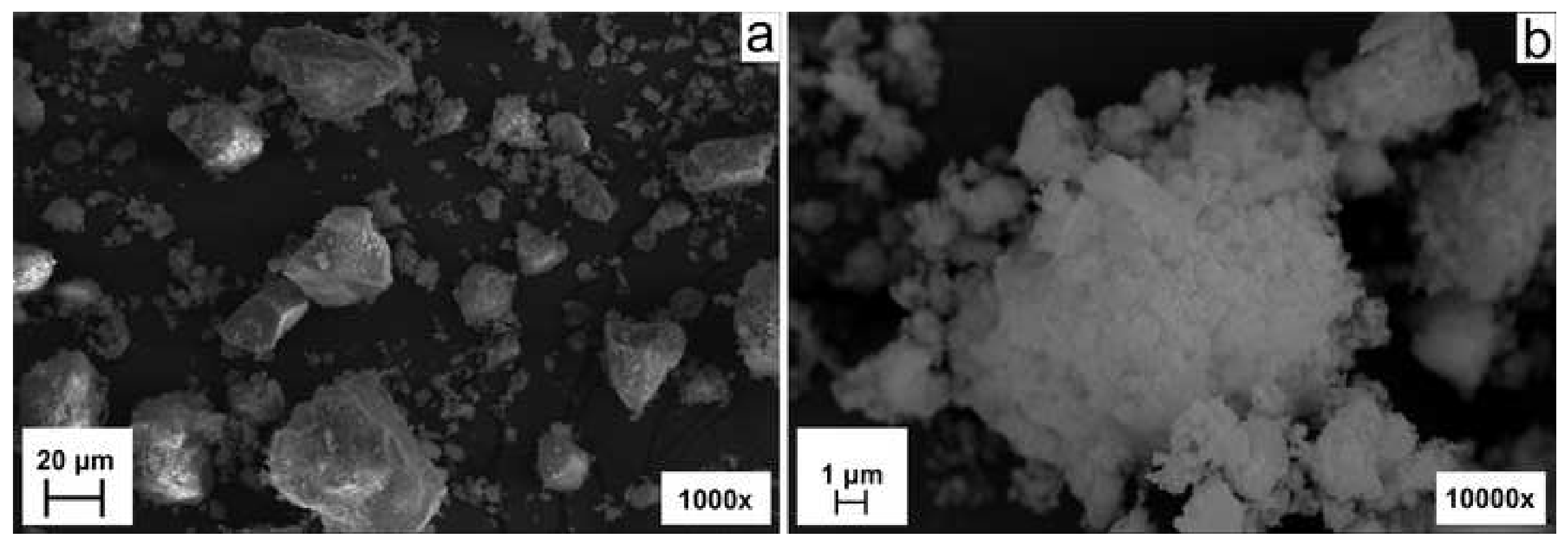




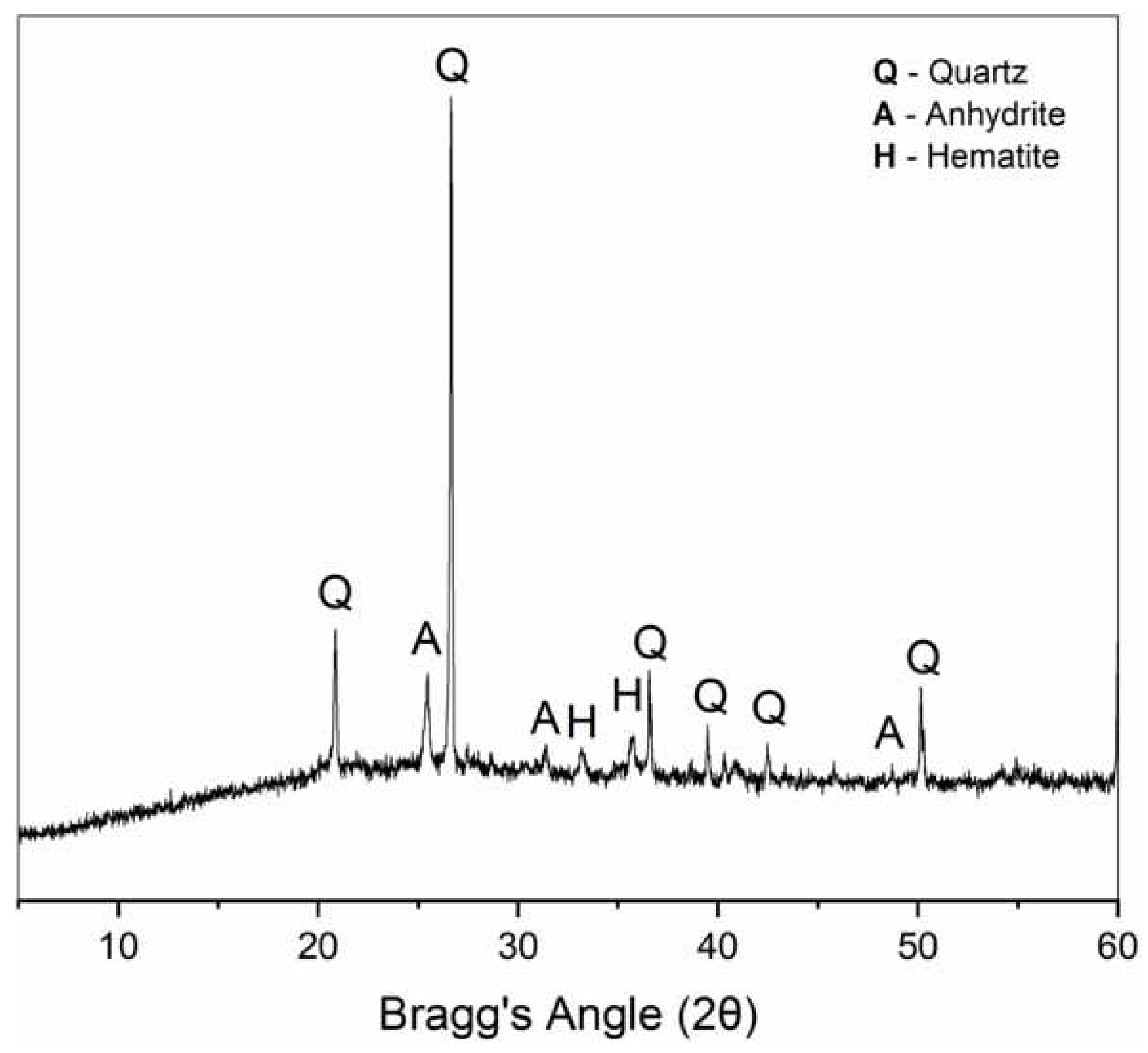




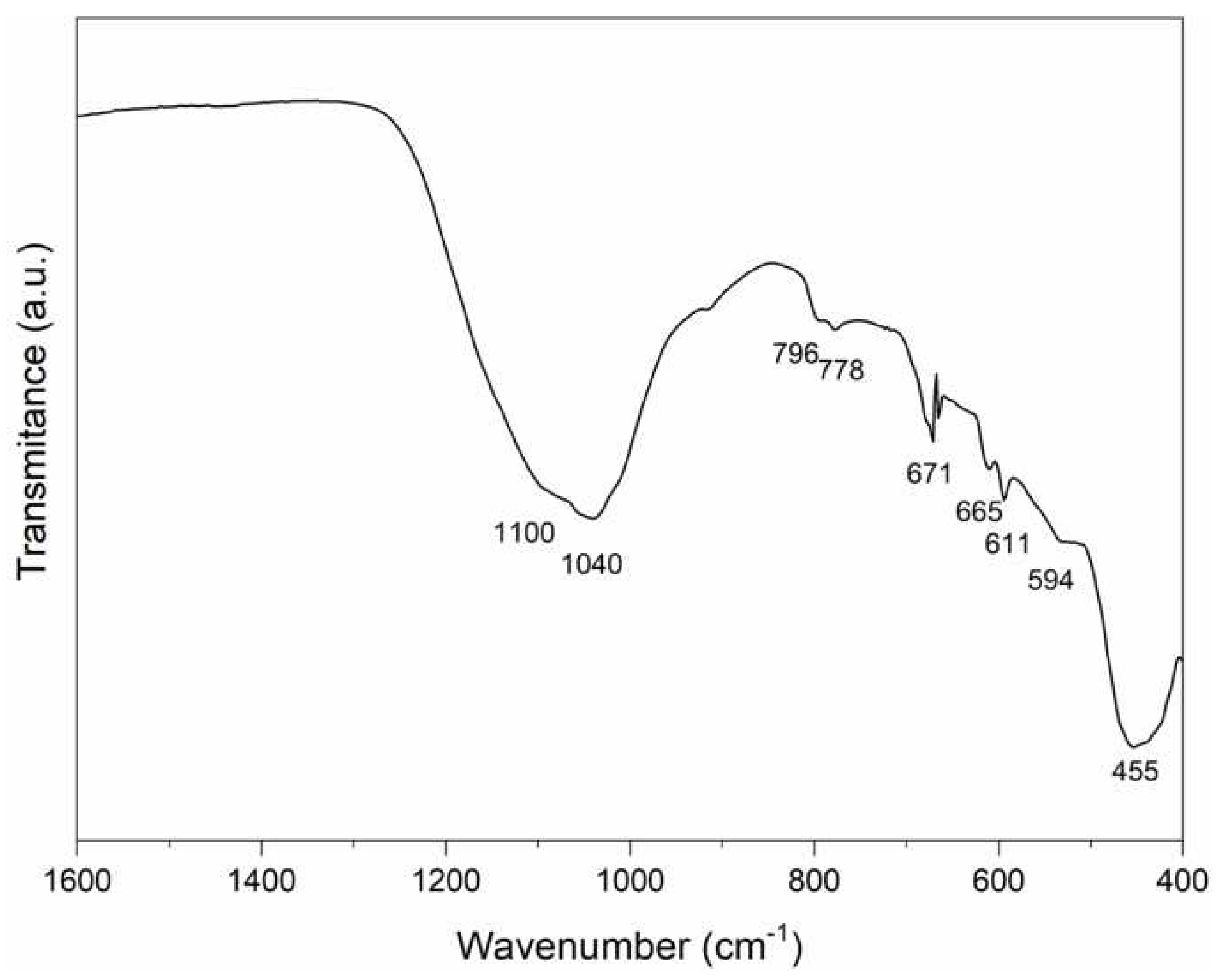




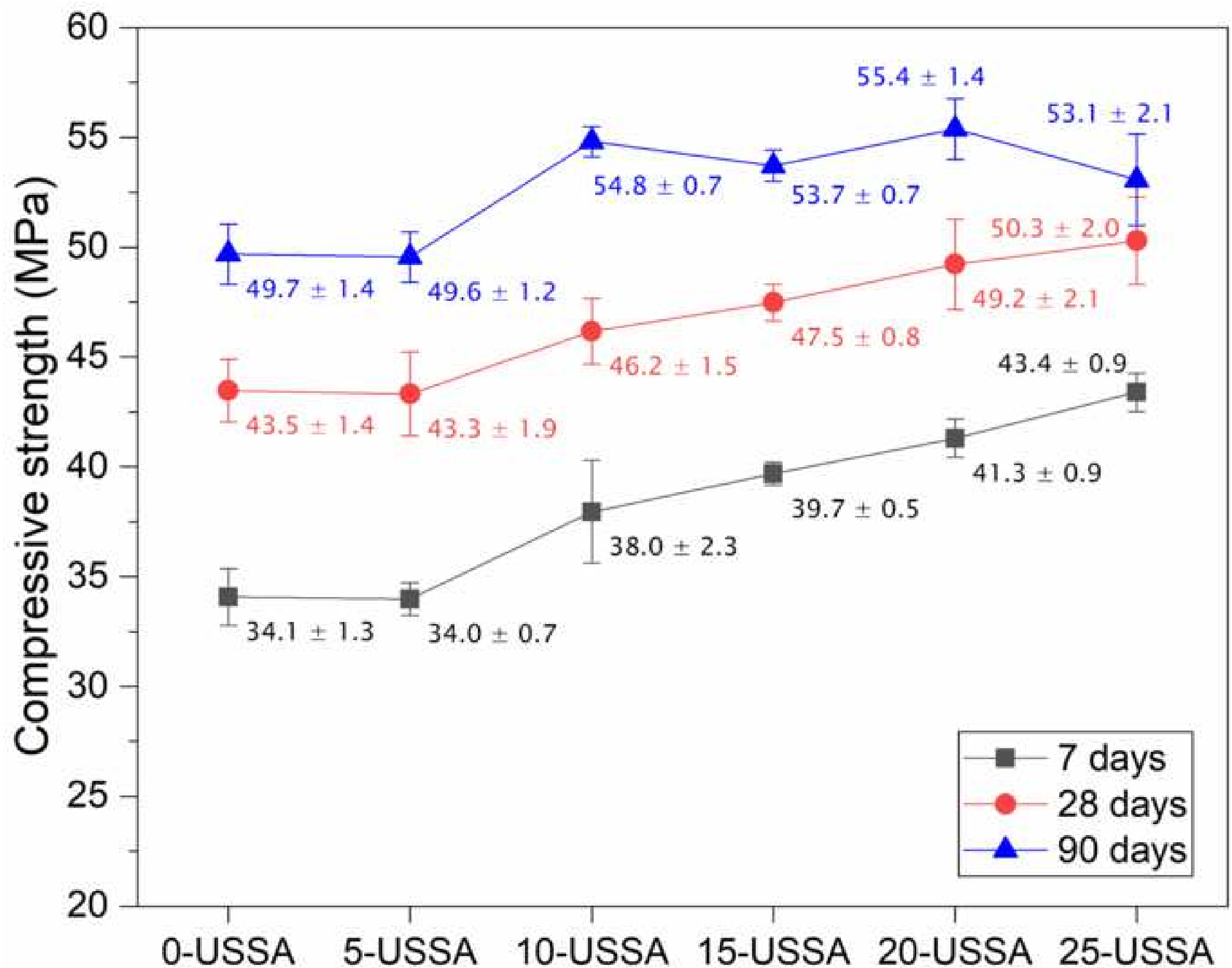




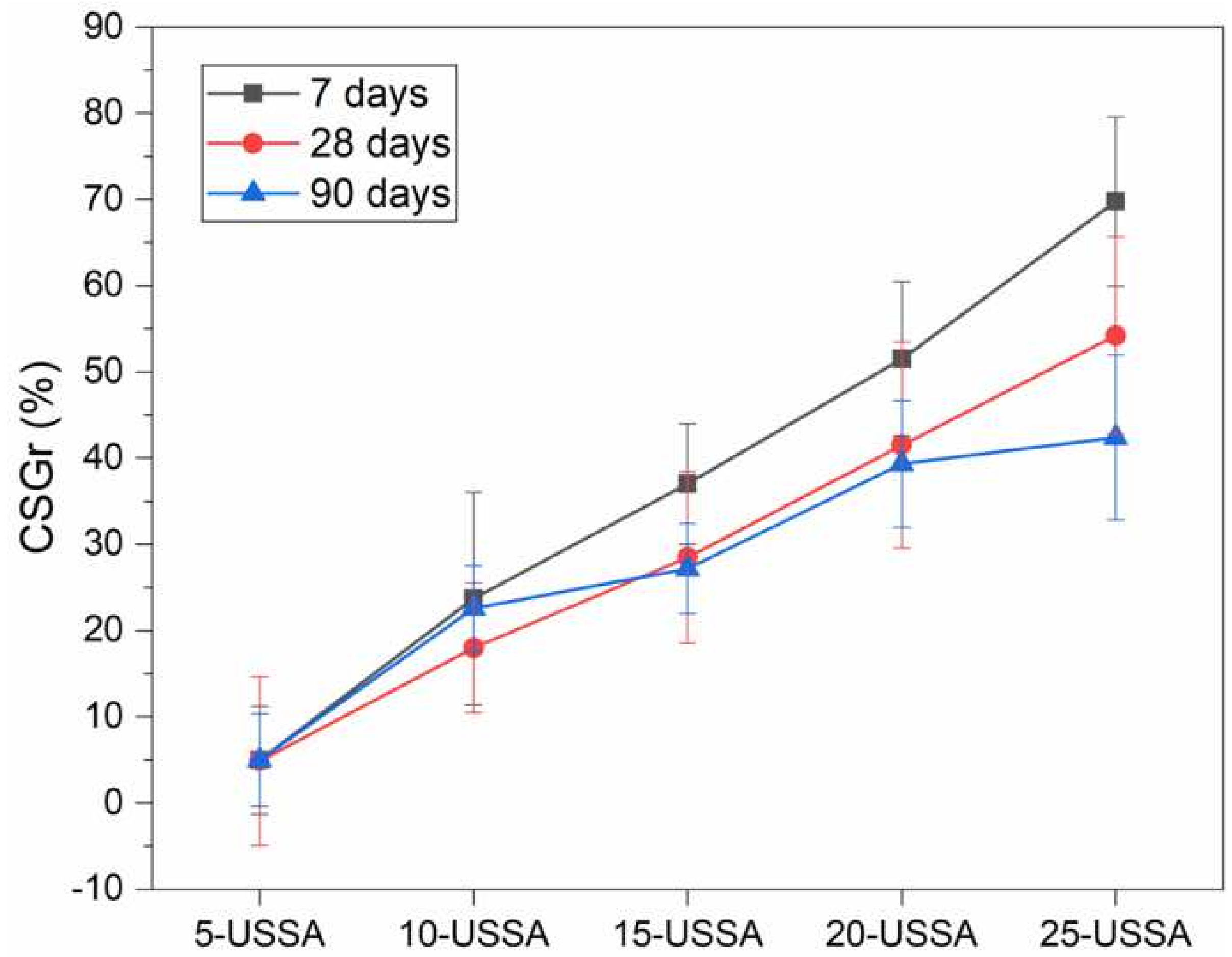



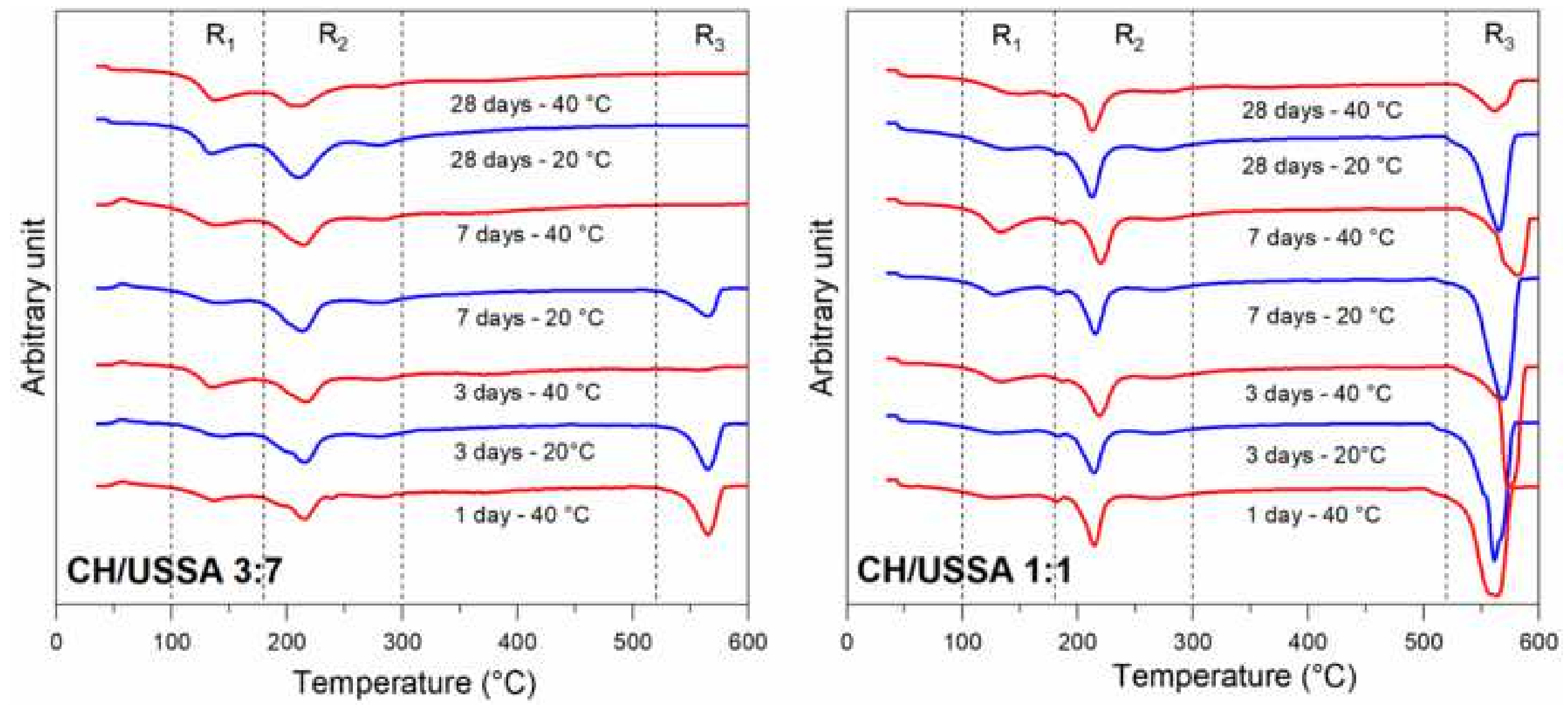


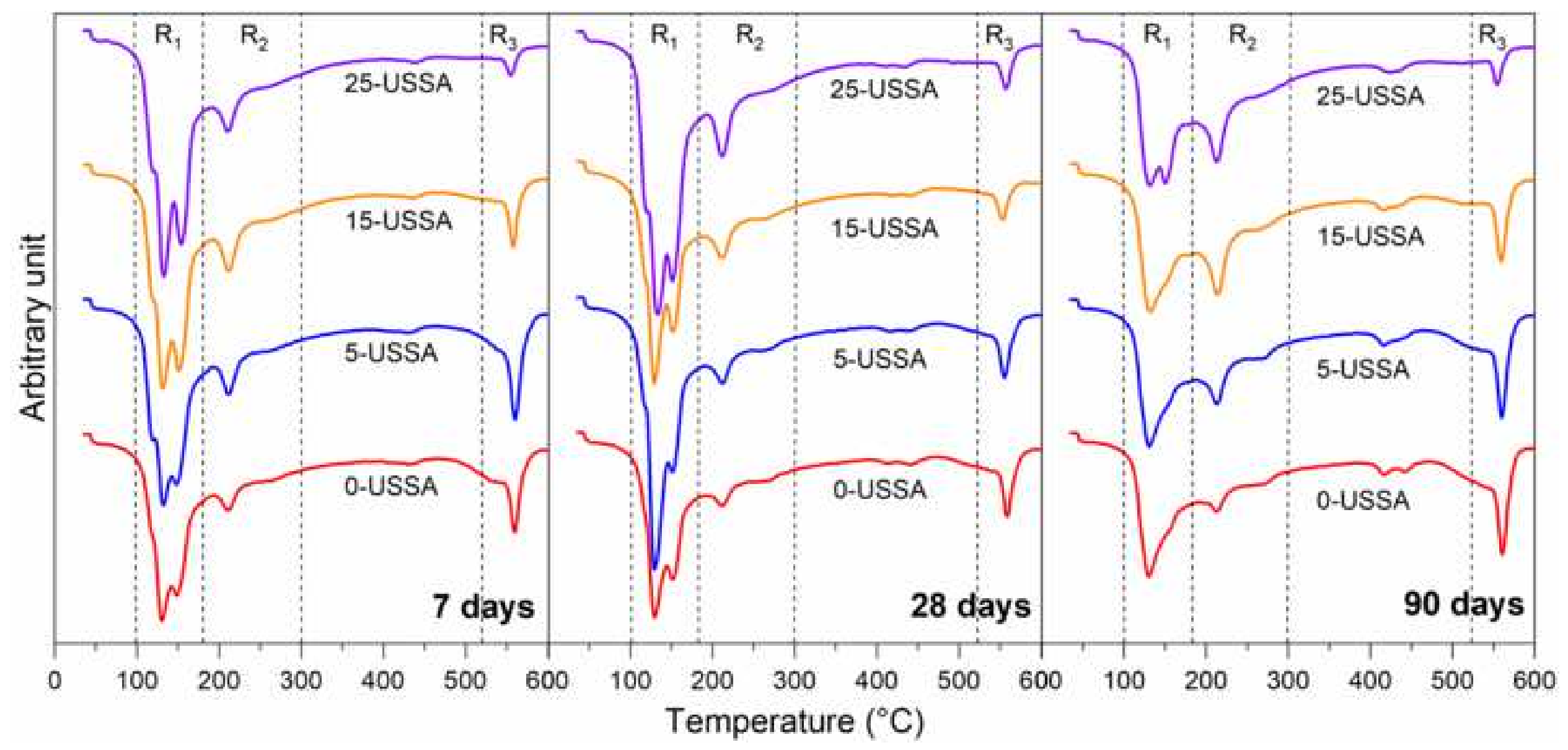



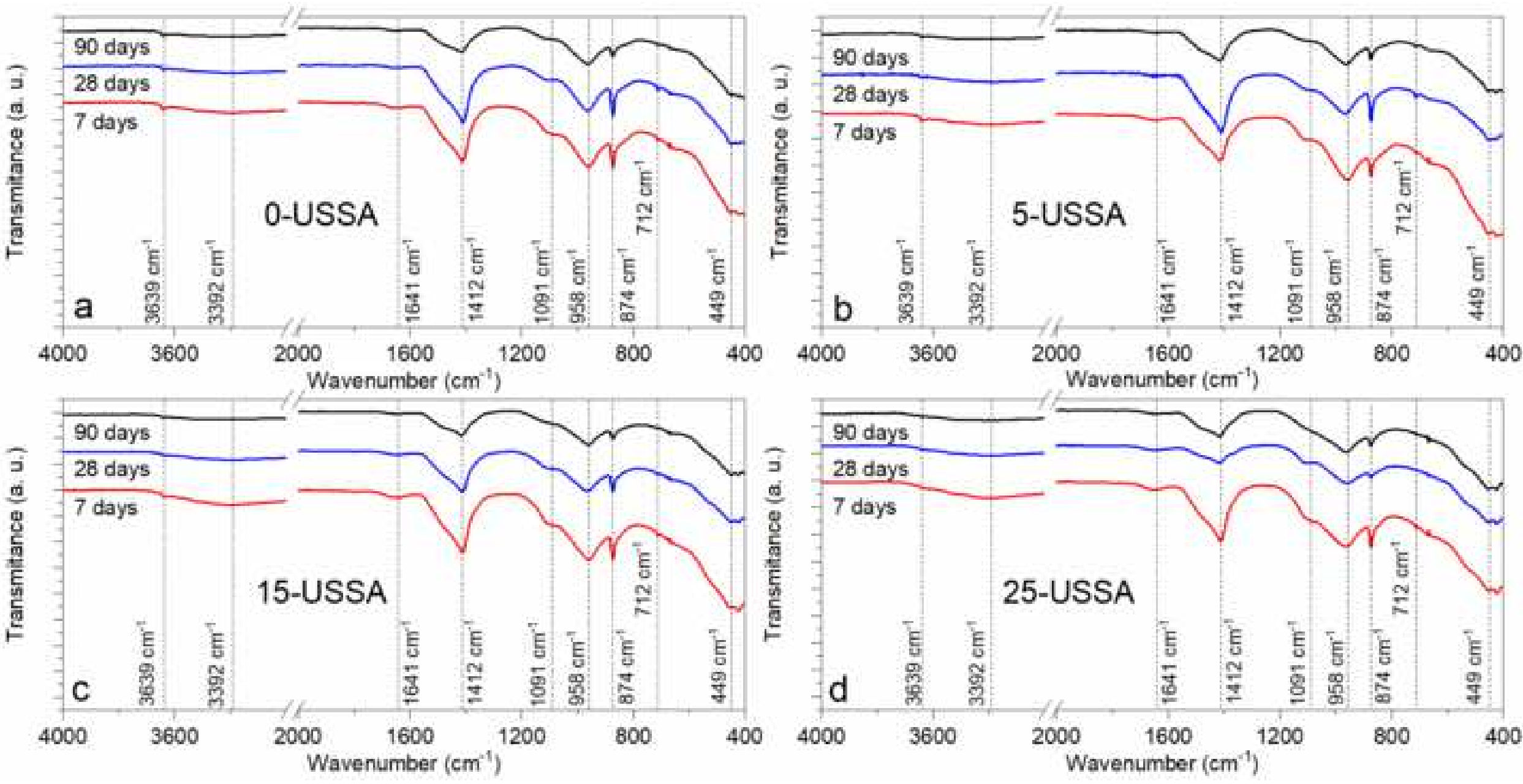
- Portlandite * Calcite ^ Gypsum • Quartz • Ettringite * Brucite $\diamond$ Carboaluminate \# Monosulfate
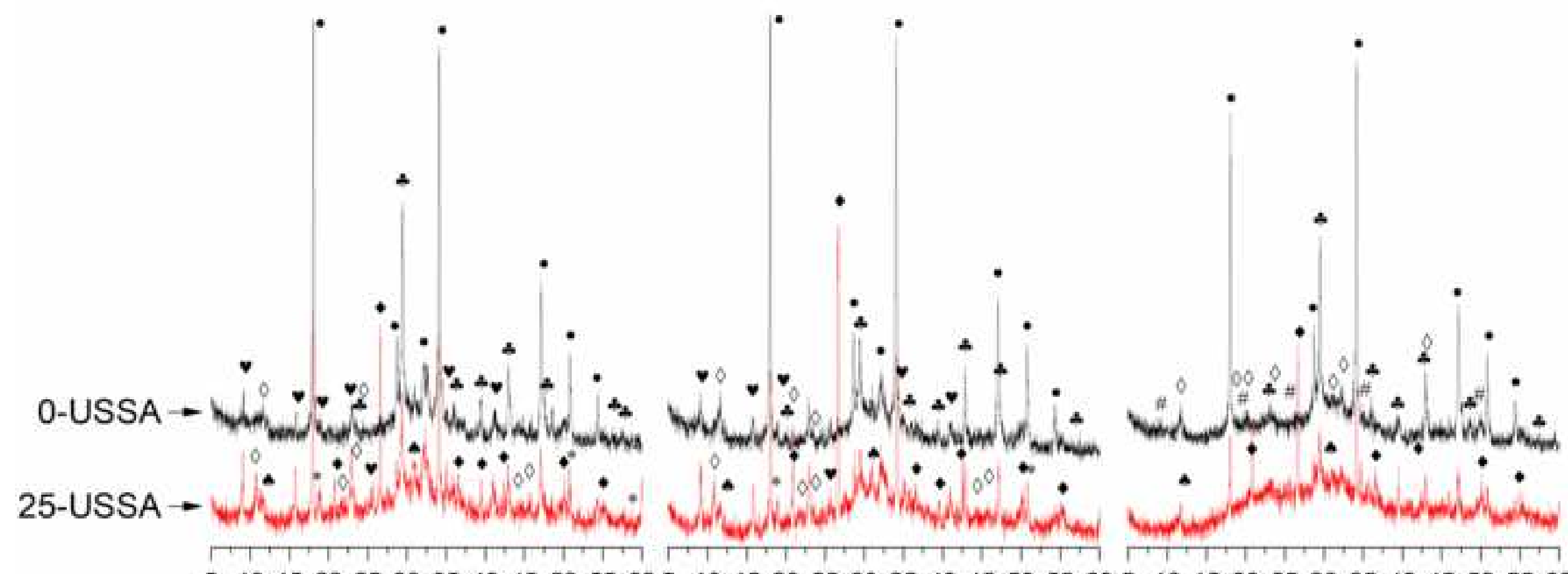

$5101520253035404550556051015202530354045 \quad 50556051015202530 \quad 354045 \quad 505560$

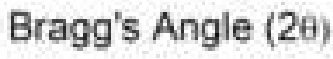
Bragg's Angle (20) Bragg's Angle (2 $\theta)$

(a) 7 days

(b) 28 days

(c) 90 days 


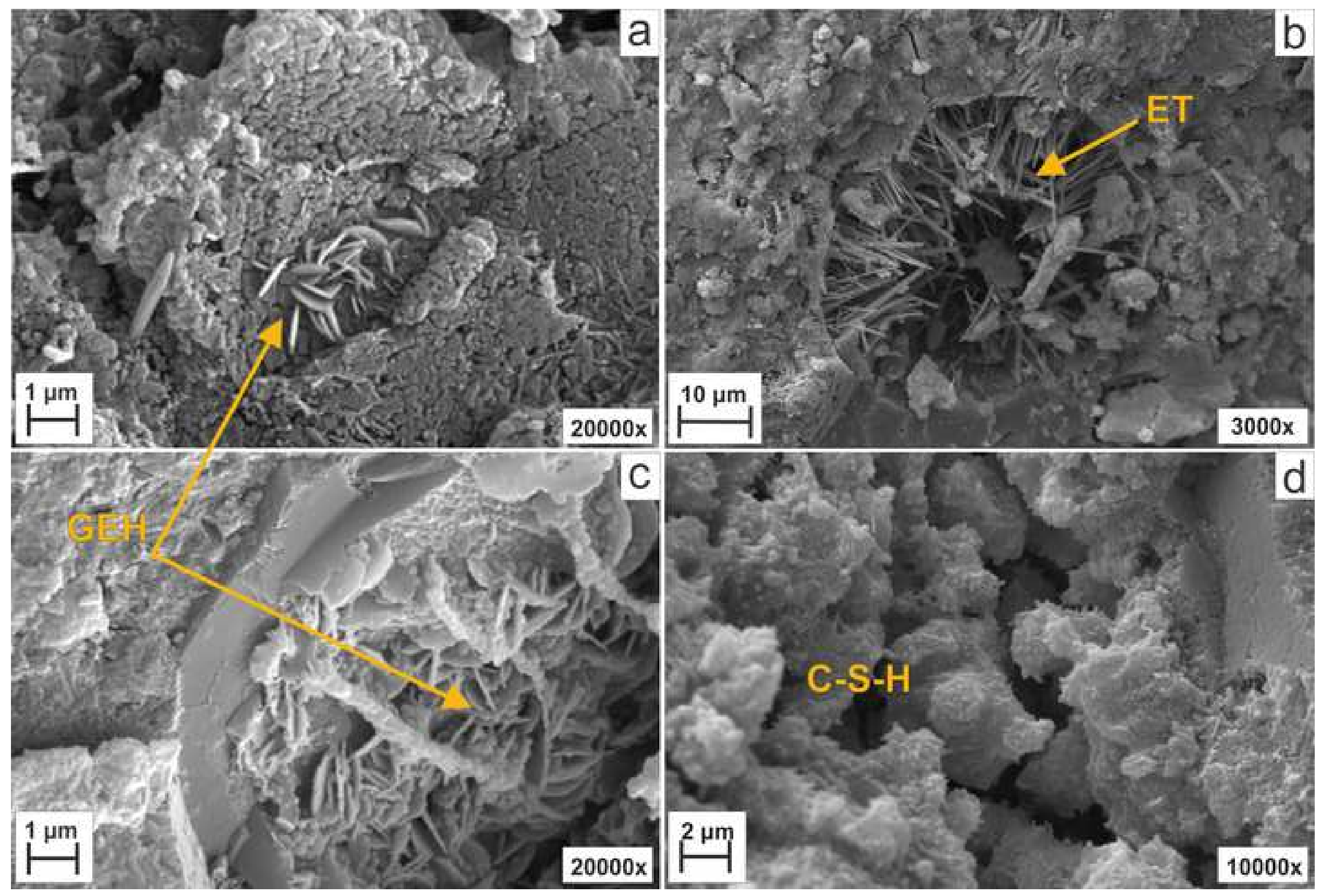




\section{Figure Caption}

Fig. 1. Process followed to obtain the uncontrolled-combusted sewage sludge ash.

Fig. 2. Temperature profile during the uncontrolled-combustion of the dried-granular sewage sludge.

Fig. 3. Granulometric distribution of milled USSA and unmilled USSA.

Fig. 4. SEM micrographs of milled USSA: a) magnification of 1000x; b) magnification of 10000x.

Fig. 5. XRD pattern of milled USSA.

Fig. 6. FTIR of milled USSA.

Fig. 7. Compressive Strength of the PC/USSA mortar samples cured from 7 to 90 days.

Fig. 8. Relative compressive strength gain registered by the PC/USSA mortars containing $5 \mathrm{wt} . \%$ to 25 wt.\% USSA, cured for 7, 28, and 90 days.

Fig. 9. DTG curves for the CH/USSA pastes prepared with a mass ratio of 3:7 and 1:1, cured at 20 and $40^{\circ} \mathrm{C}$ for $1,3,7$, and 28 days.

Fig. 10. DTG curves of PC/USSA pastes prepared with 100 wt.\% PC (0-USSA) and 5-25 wt.\% USSA (5-USSA, 15-USSA, 25-USSA), cured at $25^{\circ} \mathrm{C}$ for 7, 28, and 90 days.

Fig. 11. FTIR spectra of the PC/USSA pastes prepared with 0 wt.\% USSA (a) 5 wt. $\%$ USSA (b), 10 wt.\% USSA (c) and $25 \mathrm{wt} . \%$ USSA (d); all of them cured at $25^{\circ} \mathrm{C}$ for 7,28 , and 90 days.

Fig. 12. XRD spectra of the reference paste (0 USSA - black line) and the PC/USSA paste prepared with 25 wt.\% USSA (25 USSA - red line); samples were cured at room temperature for (a) 7 days, (b) 28 days, and (c) 90 days.

Fig. 13. SEM micrographs of the 0 -USSA paste cured for 28 (a) and 90 days (b), and the 25-USSA paste cured for 28 (c) and 90 days (d). Ettringite (ET), hydrated gehlenite (GEH), and C-S-H gels (C-S-H). 